\title{
Trajetórias de escritores e os saraus literários nas periferias de São Paulo
}

DOI: https://doi.org/10.22409/pragmatizes.v12i22.51466

\section{Lívia Lima da Silva ${ }^{1}$ Graziela Serroni Perosa}

Resumo: A pesquisa constituiu em objeto de estudo a emergência de saraus literários nas periferias da cidade de São Paulo, entre 2014 e 2016, por meio do estudo das trajetórias de seus escritores. Articulando as dimensões da cultura e da educação, a pesquisa se concentrou nos estudos sobre cultura, sob a perspectiva sociológica de Pierre Bourdieu, interrogando os processos históricos de aquisição de capital cultural, relacionando origem social, trajetória escolar e os saraus literários. $\mathrm{O}$ trabalho de campo foi realizado em quatro saraus literários, em diferentes regiões de São Paulo. Visando a identificar a posição dos bairros nos quais os saraus acontecem, e onde faríamos a pesquisa de campo em seguida, realizamos um estudo estatístico das características sociodemográficas da população residente nestes bairros. Por meio da consulta a redes sociais (Facebook), compusemos uma primeira lista de 22 saraus literários que aconteciam regularmente em São Paulo, com atividades divulgadas em redes sociais. Em seguida, definimos aqueles nos quais conduzimos as entrevistas semi-estruturadas e as observações diretas, com líderes de quatro saraus. As entrevistas tiveram como objetivo reconstruir a trajetória escolar, os demais movimentos culturais dos quais participaram e as disposições adquiridas neste processo, visando a lançar luz sobre a emergência dos saraus literários que floresceram em São Paulo no período. Para obter informações sobre o público presente nos saraus pesquisados, aplicamos um questionário (em papel), com o qual produzimos informações sobre a escolaridade, a origem geográfica, a idade, etc. Concluiu-se que, o acesso à escolarização, especialmente, o acesso ao ensino superior, contribuiu de maneira decisiva para a formação de disposições voltadas para a atuação no campo literário, tanto por parte dos poetas e escritores, como por parte do público. Residentes nas periferias de São Paulo, eles são egressos do ensino superior e da escola secundária. Dentre os escritores, muitos deles são diplomados em Letras e buscam desenvolver essas práticas literárias de forma profissional, contornando assim a exclusão dos circuitos dominantes da literatura na cidade.

Palavras-chave: Literatura; Periferia; Saraus literários; Capital Cultural.

\section{Trayectorias de los escritores y los saraos literarios en las periferias de São Paulo}

Resumen: La investigación constituyó en objeto de estudio el surgimiento de saraus literarios en las periferias de la ciudad de São Paulo, entre 2014 y 2016, a través del estudio de las trayectorias de

\footnotetext{
${ }^{1}$ Lívia Lima da Silva. Mestre em Estudos Culturais pela Universidade de São Paulo (EACH-USP), Brasil. E-mail: livialimasilva@gmail.com - https://orcid.org/0000-0001-7032-5941

${ }^{2}$ Graziela Serroni Perosa. Doutora em Educação pela Universidade Estadual de Campinas (Unicamp). Professora Associada da Escola de Artes, Ciências e Humanidades da Universidade de São Paulo (EACH/USP), Brasil. E-mail: grazielaperosa@yahoo.com.br - https://orcid.org/0000-00019575-0602
} 
SILVA, Lívia Lima da; PEROSA, Graziela Serroni. Trajetórias de escritores e os saraus literários nas periferias de São Paulo. PragMATIZES - Revista Latino-Americana de Estudos em Cultura, Niterói/RJ, Ano 12, n. 22, p. 79-112, mar. 2022.

\author{
pragMATIZES \\ www.periodicos.uff.br/pragmatizes - ISSN 2237-1508 \\ (Dossiê "Coletivos culturais - resistências, disputas e potências")
}

sus escritores. Articulando las dimensiones de la cultura y la educación, la investigación se centró en los estudios sobre la cultura, bajo la perspectiva sociológica de Pierre Bourdieu, cuestionando los procesos históricos de adquisición del capital cultural, relacionando el origen social, la trayectoria escolar y el saraus literarios. El trabajo de campo se realizó en cuatro saraus literarios, en diferentes regiones de São Paulo. Con el objetivo de identificar la posición de los barrios en los que se desarrollan los saraus, y en los que luego realizaríamos la investigación de campo, realizamos un estudio estadístico de las características sociodemográficas de la población que reside en estos barrios. Consultando las redes sociales (Facebook), compusimos una primera lista de 22 saraus que ocurren regularmente en São Paulo, con actividades publicitadas en las redes sociales. Después, definimos aquellos en los que realizamos las entrevistas semiestructuradas y las observaciones directas, con líderes de cuatro saraus. Las entrevistas pretendían reconstruir la trayectoria escolar, los movimientos culturales en los que participaron y las disposiciones adquiridas en este proceso, con el objetivo de arrojar luz sobre el surgimiento de los saraus literarios que florecieron en São Paulo en el periodo. Para obtener información sobre el público presente en los saraus investigados, aplicamos un cuestionario (en papel), con el que elaboramos información sobre la escolaridad, el origen geográfico, la edad etc. Se llegó a la conclusión de que el acceso a la escolarización, especialmente el acceso a la enseñanza superior, contribuyó decisivamente a la formación de disposiciones destinadas a actuar en el ámbito literario, tanto por parte de los poetas y escritores, como por parte del público. Residentes en las periferias de São Paulo, son graduados de educación superior y secundaria. Entre los escritores, muchos de ellos son licenciados en Literatura y buscan desarrollar estas prácticas literarias profesionalmente, sorteando así la exclusión de los circuitos dominantes de la literatura en la ciudad.

Palabras clave: Literatura; Periferia; Saraus; Capital cultural.

\section{The trajectories of writers and the literary saraus in the outskirts of São Paulo}

Abstract: The research constituted as object of study the emergence of poetry soirees in the outskirts of the city of São Paulo, between 2014 and 2016, through the study of the trajectories of their writers. Articulating the dimensions of culture and education, the research focused on studies about culture, from the sociological perspective of Pierre Bourdieu, questioning the historical processes of acquisition of cultural capital, relating social origin, school trajectory and the poetry soirees. The fieldwork was carried out in four poetry soirees, in different regions of São Paulo (south, north, east). Aiming to identify the position of the neighborhoods in which the soirees take place, and where we would conduct the field research next, we carried out a statistical study of the sociodemographic characteristics of the population residing in these neighborhoods. By consulting social networks (Facebook), we composed a first list of 22 events that regularly took place in São Paulo, with activities publicized on social networks. Then, we defined those in which we conducted the semi-structured interviews and direct observations, with leaders of four saraus. The interviews aimed to reconstruct their school trajectory, the other cultural movements in which they participated, and the dispositions acquired in this process, in order to shed light on the emergence of the poetry soirees that flourished in São Paulo during the period. To obtain information about the public present in the researched, we applied a questionnaire (on paper), with which we produced information about schooling, geographical origin, age, etc. We concluded that access to schooling, especially access to higher education, contributed decisively to the formation of dispositions towards acting in the literary field, both on the part of poets and writers, and on the part of the public. Resident in the outskirts of São Paulo, they are graduates of higher education and high school. Among the writers, many of them have a degree in Literature and seek to develop these literary practices professionally, thus circumventing the exclusion from the dominant circuits of literature in the city.

Keywords: Literature; Periphery; Poetry soirées; Cultural Capital. 


\section{Trajetórias de escritores e os saraus literários nas periferias de São Paulo}

\section{As periferias e as desigualdades de acesso à cultura \\ O termo periferia no Brasil, mais} que substantivo que delimita espaços geográficos, se configurou como uma espécie de adjetivo, classificando territórios por condições socioeconômicas, caracterizando situações de pobreza e violência, sendo estas consequências da ausência de investimentos e políticas específicas para esses locais, mas que no senso comum, entretanto, provocam o preconceito e a estigmatização das regiões periféricas e de seus habitantes como os principais responsáveis por esses fenômenos.

Bourdieu considerava que a distância geográfica e a ausência ao acesso a determinados direitos configuram condições sociais que restringem a determinados grupos sociais a participação da constituição dos "valores", ou, em outros termos, poderíamos considerar como os diversos capitais (econômico, cultural, político):

a distância social real de um grupo a determinados bens deve integrar a distância geográfica que, por sua vez, depende da distribuição do grupo no espaço e, mais precisamente, de sua distribuição em relação ao "núcleo de valores" econômicos e culturais [...] (BOURDIEU, 2008, p.114).

Os espaços periféricos são amplamente descritos por urbanistas e cientistas sociais como territórios em que se sobrepõem precariedade habitacional, políticas públicas insuficientes de infraestrutura pública, e a discriminação dos seus moradores, o que significa estar associado a um destino baseado em uma característica atribuída por terceiros e fonte de discriminação e preconceito (CASTEL, 2008).

São vítimas desta discriminação os migrantes nordestinos em São Paulo, boa parte deles, negros, portanto, cuja posição e destino social são fortemente marcados pelo duplo pertencimento de classe e o pertencimento étnico-racial, duramente atingidos pelo emprego precário, pelo abandono precoce da escola e, especialmente expostos, aos efeitos deletérios da violência policial. Esse 
"tipo ideal", no sentido weberiano, tão presente na mídia e no senso comum, é definido pela associação entre jovens que abandonaram o sistema de ensino por absoluta necessidade de trabalhar, habitantes das periferias das grandes cidades brasileiras $\mathrm{e}$ trabalhadores precarizados. Eles se opõem aos que, apesar de tudo, lograram continuar a estudar, via de regra, como estudantes trabalhadores e que farão todo o possível, para reinventar sua condição. Esta pesquisa buscou compreender essa fração dos grupos populares.

Tereza Caldeira aponta para as características que compõem o sentido simbólico que o termo periferia incorpora a partir da falta de acesso a serviços fundamentais, sendo o espaço caracterizado como "precário, carente, desprivilegiado" (CALDEIRA, 1984 , p. 7). Em um dos primeiros estudos que refletiram sobre as condições das periferias, Nabil Bonduki e Raquel Rolnik relacionam a constituição das periferias a uma condição social da classe trabalhadora (BONDUKI; ROLNIK: 1979; KOWARICK, 1979; CABANES; Georges, 2011).
$\mathrm{Na}$ obra Punir os pobres, Wacquant demonstra, a partir do contexto norte-americano, uma espécie de criminalização da pobreza que culpabiliza as próprias vítimas pelos contextos estruturais a que são submetidas (2001). Diante do preconceito contra a população negra e periférica no Brasil, emergiu alguns grupos nesses territórios que se contrapõem a esse estigma.

O sociólogo Tiaraju d'Andrea Pablo analisa em "A formação dos Sujeitos Periféricos", que a partir dos anos 1990 o termo periferia passa a ser utilizado não apenas pelos estudos sobre a questão urbana, mas passa a ser assumido pelos seus moradores, sobretudo, por membros dos movimentos sociais insurgentes, fortemente influenciados pela cultura hip-hop.

É nesse momento que ocorre de maneira embrionária a utilização do termo periferia, como uma crítica aprofundada à sociedade e como subjetividade compartilhada e reconhecimento mútuo de uma condição (PABLO, 2013, p. 45).

Considerando-se a distância geográfica e social dos moradores das periferias de São Paulo dos equipamentos culturais da cidade, 
SILVA, Lívia Lima da; PEROSA, Graziela Serroni. Trajetórias de escritores e os saraus literários nas periferias de São Paulo. PragMATIZES - Revisto Latino-Americana de Estudos em Cultura, Niterói/RJ, Ano 12, n. 22, p. 79-112, mar. 2022.

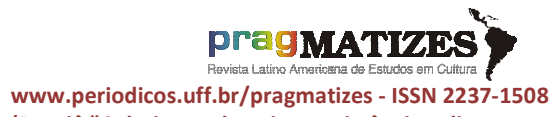

(Dossiê "Coletivos culturais - resistências, disputas e potências") como explicar a emergência dos

saraus literários que se espalharam em várias dessas regiões da cidade?

Esta pesquisa buscou analisar essa fração dos grupos populares que, por diversas razões, logrou ingressar no ensino superior e a buscar a reinventar a condição de classe trabalhadora convencional, e se apropriou de habitus de uma convencional elite cultural, sobretudo ao que se refere às práticas literárias ${ }^{3}$.

Uma das apostas centrais das rivalidades literárias (etc.) é o monopólio da legitimidade literária, ou seja, entre outras

\footnotetext{
${ }^{3}$ A noção de habitus, na perspectiva sociológica desenvolvida por Pierre Bourdieu, possui a dupla função de fundar sua compreensão da ação dos agentes e de suas visões de mundo. As relações sociais e os estilos de vida que estruturam o espaço social são mediadas pelo habitus. Com este conceito, o autor buscou ultrapassar o subjetivismo da fenomenologia e do existencialismo (Merleau Ponty, Jean-Paul Sartre, etc.) e o objetivismo das teorias econômicas, entre outras, que pressupõem um sujeito racional e livre para fazer escolhas. Sendo o resultado da incorporação da estrutura social durante o processo de socialização, a noção de habitus reintegra a experiência dos agentes à estrutura social. Sem ser um esquema de ação fixo e prédeterminado, o habitus restitui uma dimensão inventiva à ação na medida em que a incorporação das relações sociais daria origem às disposições. Sendo derivado do passado e, portanto, da inculcação dos valores sociais, o habitus ao mesmo tempo, comporta incertezas e capacidade de mudança, de adaptação. Para uma discussão mais aprofundada, consultar: SAPIRO, Gisele (org.). In: Dictionnaire Internacional Bourdieu. Paris: Editions CNRS, 2020.
}

coisas, o monopólio de poder de dizer com autoridade quem está autorizado a dizer-se escritor (etc.) ou mesmo a dizer quem é escritor e quem tem autoridade para dizer quem é escritor; ou, se preferir, o monopólio do poder de consagração de produtores ou dos produtos (BOURDIEU, 2002, p. 253).

\section{Para} compreender as especificidades dos territórios periféricos de São Paulo, esta pesquisa se concentrou inicialmente em realizar um levantamento dos dados públicos com informações demográficas, econômicas, sociais destes territórios e relacionadas também com a disponibilização e acesso a bens culturais. $O$ banco de dados é formado por estatísticas públicas disponibilizadas pela Prefeitura de São Paulo, por meio do portal da internet Infocidade, que disponibiliza dados dos Censos Populacionais do IBGE na escala dos distritos e subprefeituras da cidade. A maior parte dos dados utilizados foi extraída do último censo populacional (IBGE/2010), complementados por alguns dados de 2014 e enriquecidos com dados administrativos a respeito de equipamentos culturais disponíveis nas 31 subprefeituras de São Paulo. A seguir apresentamos os principais 
SILVA, Lívia Lima da; PEROSA, Graziela Serroni. Trajetórias de escritores e os saraus literários nas periferias de São Paulo. PragMATIZES - Revisto Latino-Americana de Estudos em Cultura, Niterói/RJ, Ano 12, n. 22, p. 79-112, mar. 2022.

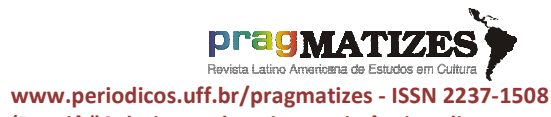

(Dossiê "Coletivos culturais - resistências, disputas e potências") resultados desta pesquisa combinando o uso de diferentes técnicas e métodos de pesquisa.

\section{Espaço social, modificações dos} grupos populares e os saraus literários em São Paulo.

A noção de espaço social foi desenvolvida por Bourdieu e seus colaboradores no livro "A Distinção" (1979) e retomada em diversos outros trabalhos posteriores (BOURDIEU, 1989; 2002) e procura reconstruir a estrutura social de maneira multidimensional e relacional. Com isso, busca ultrapassar as representações empobrecidas das divisões sociais e suas hierarquias, materializadas nas teorias da estratificação social predominantes nos países anglo saxões e dominante na pesquisa em ciências sociais ainda hoje (DUVAL, 2021). Que hierarquizam a população, a pirâmide social, com base em seus aspectos predominantemente econômicos, com menor atenção aos aspectos relacionados ao capital cultural ${ }^{4}$. Nos

\footnotetext{
${ }^{4}$ Sem negligenciar o peso do capital econômico (renda e patrimônio), considera-se que o capital cultural, especificamente, em sua forma institucionalizada, como os diplomas
}

estudos de Bourdieu, o espaço social definia-se primeiramente com base no volume do capital (econômico, cultural, social e simbólico) e em seguida, com base na composição do capital, e particularmente, do peso relativo do capital cultural na estrutura de capitais ${ }^{5}$. Para Bourdieu, o problema das classes sociais não pode ser compreendido sem fazer referência a essas diferentes formas de capital entendidos como recursos protetores e que conferem poder aos seus detentores - que definem as hierarquias sociais que atravessam uma dada estrutura social. Sem negligenciar $\circ$ peso do capital econômico (renda e patrimônio), considera-se que o capital cultural, especificamente, em sua forma institucionalizada, como os diplomas educacionais, mas não só, constituemse um princípio de hierarquização das sociedades contemporâneas.

Estas noções formuladas por Bourdieu e sua equipe no contexto europeu da segunda metade do século

educacionais mas não só, constitui-se um princípio de hierarquização da sociedade.

${ }^{5}$ Uma excelente exposição da noção de espaço social pode ser encontrada em: BOURDIEU, Pierre. Espaço social e gênese das "classes. In: O poder simbólico. Rio de Janeiro: Bertrand Brasil. p. 133-161. 
SILVA, Lívia Lima da; PEROSA, Graziela Serroni. Trajetórias de escritores e os saraus literários nas periferias de São Paulo. PragMATIZES - Revisto Latino-Americana de Estudos em Cultura, Niterói/RJ, Ano 12, n. 22, p. 79-112, mar. 2022.

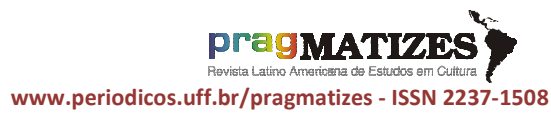

(Dossiê "Coletivos culturais - resistências, disputas e potências")
XX, foram operacionalizadas neste estudo com informações que julgamos pertinentes para o contexto brasileiro, dentre aquelas informações disponíveis no Infocidade e na Rede Nossa São Paulo. Importa ressaltar que transpusemos conceitos $\mathrm{e}$ esquemas explicativos, com conteúdos empíricos relativos a problemas nacionais e em muitos casos, particulares à cidade de São Paulo ${ }^{6}$. Bourdieu, não utilizou naturalmente a informação "recursos sanitários", porque esta não era uma informação pertinente para o contexto francês dos anos de 1970. Em São Paulo, essa informação foi útil para buscar distinguir, com maior acuidade, as periferias mais precárias daquelas mais estabelecidas. Enfatizamos os argumentos de estudos correlatos em outros contextos nacionais, a respeito da validade de uma transposição teórica e conceitual, desde que a partir de informações empíricas relevantes. Consideramos, principalmente, as estatísticas disponíveis nas

\footnotetext{
${ }^{6}$ O uso da noção de espaço social tem sido aplicado a diversos contextos nacionais. Ver, por exemplo, os trabalhos de Giovini (2020) na Argentina ou a pesquisa de Hjellbrekke e Korsnes (2013) baseados na noção de espaço social.
}

plataformas do Infocidade e da Rede Nossa São Paulo ${ }^{7}$.

Para tratar essas informações, de maneira coerente com a perspectiva bourdiesiana, recorremos a uma Análise de Correspondências Múltiplas, mais precisamente à uma técnica estatística chamada Análise de Componentes Principais $(\mathrm{ACP})^{8}$. A ACP cria uma representação multidimensional da cidade. Assim, foi possível analisar, a partir de 18 variáveis e suas categorias, as subprefeituras que possuíam os

\footnotetext{
${ }^{7}$ De acordo com o Infocidade este é o endereço para consultas de dados sobre a cidade de São Paulo. Alimentada pela Secretaria Municipal de Urbanismo e Licenciamento (SMUL) que coloca à disposição do público uma extensa compilação de indicadores e informações que compõem o rico acervo de seu banco de dados. As fontes são as próprias secretarias da prefeitura, responsáveis por serviços diversos oferecidos aos paulistanos, mas também instituições como o IBGE, a Fundação Seade e os Ministérios do Trabalho e Emprego, da Educação e da Saúde. Fonte:

https://www.prefeitura.sp.gov.br/cidade/secreta rias/licenciamento/desenvolvimento_urbano/da dos_estatisticos/info_cidade/index.php/ Sobre a organização não governamental, consultar a Rede Nossa São Paulo que por meio de parcerias público e privado pretendem contribuir para o aprimoramento de políticas públicas na cidade de São Paulo.

https://www.nossasaopaulo.org.br/quemsomos /\#rnsp

${ }^{8}$ Tal procedimento foi pensado como uma ferramenta de observação da estrutura social de São Paulo, com o auxílio do Software (SPAD 7.1) e seguindo as orientações metodológicas de Lebaron (2006).
} 
saraus que são eventos literários

consideradas relevantes para 0 realizados nos bairros periféricos da cidade, sobretudo, a partir de 2001. As variáveis selecionadas para a análise estatística contemplam a renda familiar dos domicílios, nível educacional e infraestrutura, considerando equipamentos de cultura e acesso a contexto da cidade de São Paulo constam 'domicílios sem saneamento básico', 'taxa de homicídios', 'bibliotecas públicas', 'matrículas no ensino médio', 'renda de até $1 / 2$ salário mínimo', 'disfunção série-idade", dentre outras.

bens culturais. Dentre as informações

Quadro 1. Informações consideradas por tipo de capital

\begin{tabular}{|c|c|c|c|}
\hline Capital econômico & Capital cultural & $\begin{array}{c}\text { Infraestrutura } \\
\text { pública }\end{array}$ & $\begin{array}{c}\text { Características } \\
\text { sociodemográficas }\end{array}$ \\
\hline $\begin{array}{l}\text { Renda domiciliar, por } \\
\text { salários mínimos (SM): } \\
\text { - } \quad \text { Até } 1 / 2 \text { SM } \\
\text { - } \quad \text { De } 1 \text { a } 2 \text { SM } \\
\text { - De } 2 \text { a } 5 \mathrm{SM} \\
\text { - } \quad \text { De } 5 \text { a } 10 \mathrm{SM} \\
\text { - Mais de } 20 \mathrm{SM}\end{array}$ & $\begin{array}{l}\text { Último diploma escolar } \\
\text { em três categorias: } \\
\qquad \quad \text { Ensino } \\
\\
\quad \text { Fundamental I } \\
\quad \text { e II } \\
\text { - Ensino médio } \\
\text { - Ensino } \\
\text { superior } \\
\text { Taxa de disfunção } \\
\text { série-idade }\end{array}$ & $\begin{array}{l}\text { Domicílios sem } \\
\text { saneamento básico } \\
\text { Bibliotecas públicas } \\
\text { Leitos públicos } \\
\text { Matrículas na escola } \\
\text { secundária }\end{array}$ & $\begin{array}{l}\text { População com mais de } \\
60 \text { anos } \\
\text { População até } 14 \text { anos } \\
\text { Taxa de fecundidade } \\
\text { Taxa de homicídio }\end{array}$ \\
\hline
\end{tabular}

Fonte: elaboração das autoras.

A partir da seleção dessas variáveis, utilizamos uma $\mathrm{ACP}$ standard que cria um sistema de eixos, podendo ser lida como uma representação do espaço social da cidade. Neste sistema de eixos, definido pela variância estatística das variáveis ativas, as subprefeituras ocupam uma posição específica, se aproximam e se distanciam umas das outras, em função de partilharem ou não, traços em comum, como o mesmo percentual da população com ensino médio, de domicílios sem saneamento básico, etc ${ }^{9}$. A partir destas informações para o conjunto da

\footnotetext{
${ }^{9}$ Para saber mais sobre a ACP e a Análise Geométrica dos dados, consultar: LEBARON, Frédéric. L'enquête quantitative en sciences sociales. Paris, DUNOD, 2006. Uma tradução deste livro para o português está no prelo e será publicada pela Editora EDUSP em 2022.
} 
SILVA, Lívia Lima da; PEROSA, Graziela Serroni. Trajetórias de escritores e os saraus literários nas periferias de São Paulo. PragMATIZES - Revista Latino-Americana de Estudos em Cultura, Niterói/RJ, Ano 12, n. 22, p. 79-112, mar. 2022.

\section{pragMATIZES}

www.periodicos.uff.br/pragmatizes - ISSN 2237-1508 (Dossiê "Coletivos culturais - resistências, disputas e potências")

população e dos domicílios da cidade ajudam a examinar e a sintetizar a de São Paulo, produzimos a ACP que composição e a distribuição da gerou as imagens abaixo que nos população nas diferentes subprefeituras.

Gráfico 1 - O espaço das subprefeituras de São Paulo.

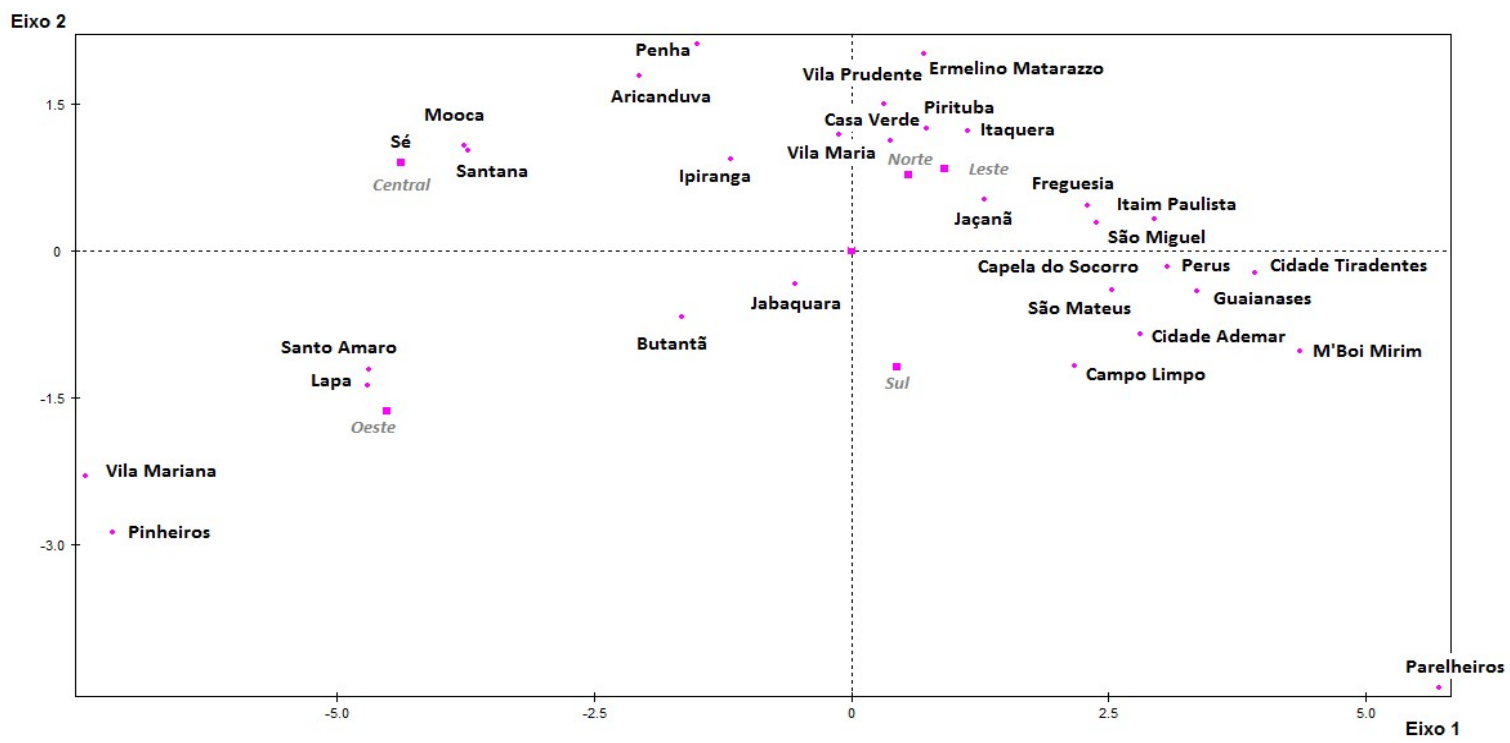

Fonte: Produzido pelas autoras com variáveis de atividades e equipamentos culturais de São Paulo, extraídos do INFOCIDADE ${ }^{10}$ e consonância com estudos anteriores (PEROSA; LEBARON; LEITE, 2015).

\footnotetext{
${ }^{10}$ Consultar:
}

https://www.prefeitura.sp.gov.br/cidade/secretarias/licenciamento/desenvolvimento_urbano/dados_est atisticos/info_cidade/cultura/ 
$\mathrm{Na} A C P$, esses os eixos 1 e 2 respondem pela maior variância estatística. O eixo 1 (horizontal) que opõe Pinheiros de Parelheiros é o eixo da grande desigualdade econômica e social. Nos quadrantes à esquerda, situam-se as regiões com maior renda e maior escolaridade e à direita, as subprefeituras das periferias que se diferenciam tanto em relação à posição no eixo 1 como em relação ao eixo 2 (vertical). A posição de cada subprefeitura no espaço social da cidade de São Paulo foi definida pela variância estatística das variáveis ativas apresentadas no Quadro 1.

O eixo 1 (horizontal) corresponde à renda e ao nível educacional, considerado uma primeira dimensão que distingue as regiões da cidade. Pinheiros e Parelheiros se opõem no eixo 1 , porque $\mathrm{o}$ primeiro possui $\mathrm{o}$ maior contingente de domicílios com mais de 20 salários mínimos e maior proporção da população com ensino superior completo. Parelheiros, ao contrário, possui o maior contingente de domicílios de até meio salário mínimo e a menor proporção da população na cidade que chegou ao ensino médio. $\mathrm{O}$ eixo 2 (vertical) foi definido pela contribuição das variáveis de ensino médio completo como último diploma da população e pela presença de maior infraestrutura pública. Se o eixo 1 dimensiona a grande desigualdade social, mais visível a olho nu, o eixo 2, distingue tanto as regiões das classes médias e altas, como as periferias da cidade, opondo aquelas que possuem maiores níveis de infraestrutura pública e maior proporção da população com a conclusão do ensino médio, das periferias mais precárias, onde há maior incidência da população vivendo em habitações sem saneamento básico, de domicílios de até meio salário mínimo e maior proporção da população adulta que concluiu apenas o ensino fundamental II. O eixo 2 nos foi especialmente útil para verificar a heterogeneidade das periferias, as posições intermediárias para além dos extremos de riqueza e pobreza.

A representação permitiu verificar a distinção entre os bairros ricos e pobres na cidade. Denota-se, que a principal dimensão que define o espaço social é a condição socioeconômica, que opõe poucas subprefeituras mais ricas e escolarizadas, presente nos 
quadrantes à esquerda do gráfico, separadas de toda uma densa nuvem de subprefeituras com maior concentração de pobreza e baixa escolaridade, à direita do eixo 2 (vertical), composta em sua maioria pelas subprefeituras das periferias de São Paulo (PEROSA; LEBARON; LEITE, 2015).

Por meio do estudo dessa estrutura de correlações estatísticas, podemos observar compreender as diferentes dimensões do espaço e a segregação na qual a cidade está estruturada e também identificar quais elementos a compõem. A seguir, examinamos a distribuição dos equipamentos culturais projetados sobre o espaço social. Por meio dessa seleção, alcançamos 0 seguinte resultado:

Gráfico 2 - Projeção de variáveis ilustrativas sobre o espaço social de São Paulo.

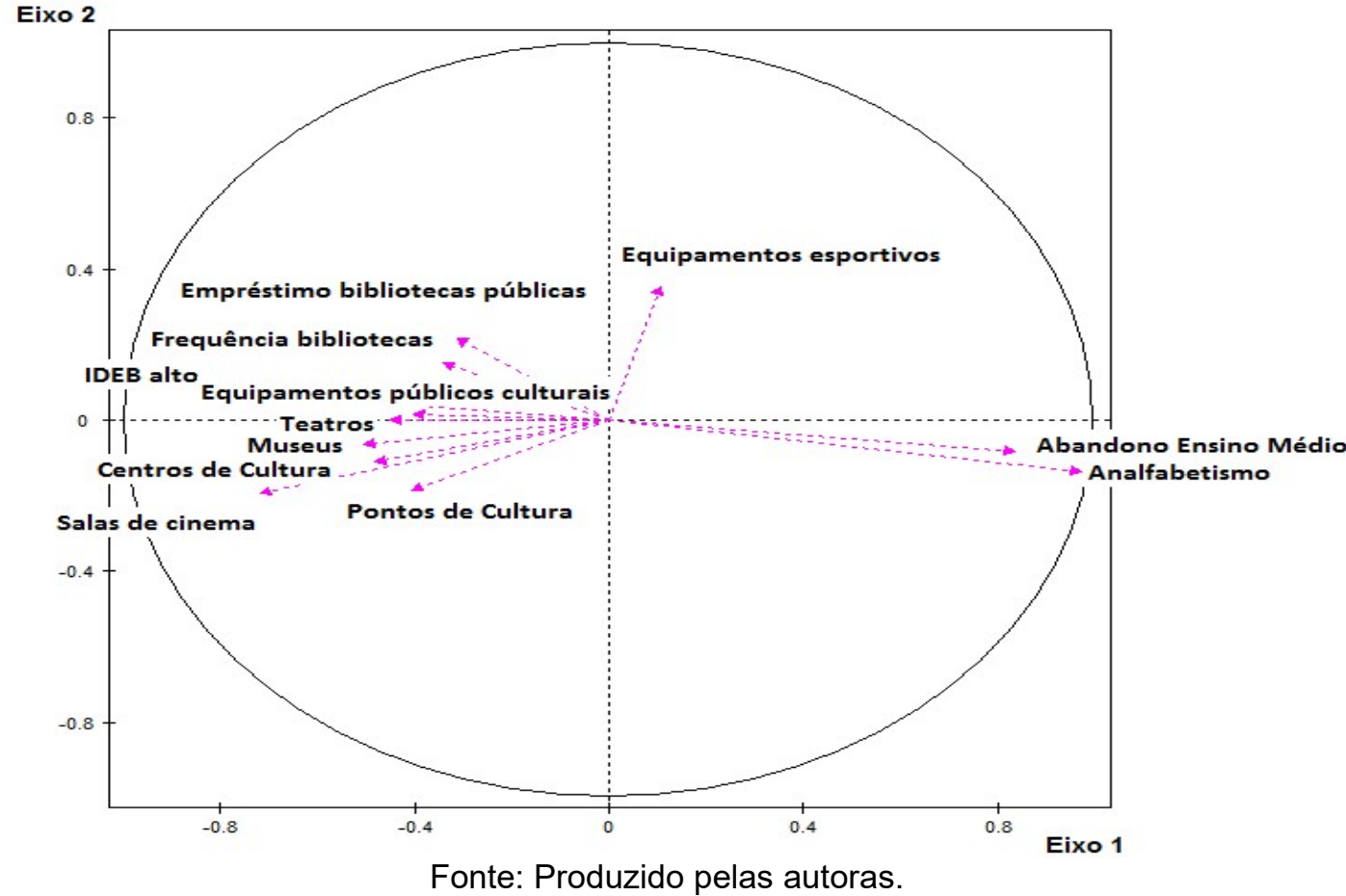

O gráfico 2 apresenta a variáveis educacionais, projetadas correlação entre as variáveis de sobre o espaço social apresentado no equipamentos culturais e outras Gráfico 1. Para a leitura desses 
gráficos é importante ainda observar os vetores ou setas, se preferirmos. Elas são muito mais incidentes nas regiões da cidade presentes nos quadrantes para as quais esses vetores apontam. Quanto mais longa a seta, mais intensa é a concentração do fenômeno nas regiões da cidade representadas no Gráfico 1. Se mais próximo do Eixo 1 (horizontal), ela se correlaciona mais fortemente com esta primeira dimensão sintetizada pelo Eixo 1 e assim, sucessivamente.

Dessa forma, podemos mencionar observando o Gráfico 2, por exemplo, como torna-se visível que os índices de abandono do ensino médio e de analfabetismo estão mais presentes nas regiões com os menores números em relação à renda e nível educacional do primeiro gráfico, que determinam o eixo 1 , como a subprefeitura de Parelheiros, identificada primeiramente no gráfico 1. Como esperado, observa-se como os equipamentos culturais se concentram nas áreas mais ricas da cidade e se afastam das zonas periféricas.

Por meio desses recursos de representação multidimensional é possível verificar como, apesar de estarem em posições distintas entre si, os bairros aos quais pertencem os saraus do objeto de estudo da pesquisa ocupam o mesmo espaço em relação às variáveis de renda e educação. Dessa forma, se evidencia que os saraus enquanto prática cultural compõem um movimento específico que emerge de uma população sob condições socioeconômicas semelhantes. A partir do surgimento de um movimento literário que emerge de bairro das periferias da cidade de São Paulo, sobretudo a partir do início dos anos 2000, constatou-se que seus integrantes se diferenciavam socialmente daqueles a quem é geralmente associado 0 perfil do escritor brasileiro.

Com base nesse pressuposto, iniciou-se uma investigação para entender as possíveis motivações e situações que propiciaram a esses sujeitos se engajarem nas atividades literárias. A partir de pesquisa bibliográfica, e em contato com resultados da pesquisa de campo, verificou-se que a evolução em acesso e tempo de ensino nas populações trabalhadoras e periféricas, contribuiu significativamente para que novos 
sujeitos se engajassem em atividades culturais.

Nas últimas décadas, a difusão dos sistemas de ensino ocorreu em quase todas as regiões do mundo e o acesso cresceu em todos os níveis de ensino. Na América Latina e no Brasil, em especial, das últimas décadas do século $X X$, logramos reduzir 0 analfabetismo.

No levantamento "Estatísticas da educação básica no Brasil" do Inep, constava que $46 \%$ da população era analfabeta entre as décadas de 60 e 70 , período em que se intensificou a constituição das periferias nas grandes cidades. Segundo a mais recente Pesquisa Nacional por Amostra de Domicílios (Pnad) Contínua Educação (IBGE/2019), a taxa de analfabetismo hoje corresponde a $6,6 \%$ da população.

A conclusão da antiga escola primária se ampliou com as políticas educativas da década de 1980 que visavam reduzir os altos índices de reprovação com as políticas de ciclos escolares. O acesso generalizado ao ensino médio brasileiro não se deu antes de 1990/2000, sendo até então altamente dependente do capital econômico das famílias e do recurso à escola privada. A partir dos anos 1990 e 2000, o acesso à educação superior também aumentou significativamente, especialmente, em função do crescimento da matrícula na educação superior privada e, em menor medida, da ampliação das vagas em universidades públicas brasileiras.

De acordo com o Censo da Educação Superior (Inep) ${ }^{11}$, em 2009, 2.065.082 pessoas ingressaram no ensino superior. Já em 2019, o número foi de 3.633.320, demonstrando um aumento significativo em dez anos. Talvez, não seja por acaso que, por volta de 2000 tenha florescido nas periferias da cidade de São Paulo uma série de iniciativas culturais buscando não apenas levar a literatura para as periferias, mas, sobretudo, produzir uma literatura a partir destas regiões da cidade. É possível verificar que há, internamente nas classes sociais, uma diversidade muito grande de atores, com posições e interesses distintos. Diante disso, não deveria ser incomum que nas periferias das grandes

\footnotetext{
${ }^{11}$ Censo da Educação Superior - Instituto Nacional de Estudos e Pesquisas Educacionais Anísio Teixeira - Inep: https://www.gov.br/inep/pt-br/areas-deatuacao/pesquisas-estatisticas-eindicadores/censo-da-educacao-superior. Acesso em 30/08/2021.
} 
cidades surjam artistas, intelectuais, escritores. Entretanto, é importante destacar que são necessárias condições materiais e sociais que propiciem esse movimento.

A hipótese geral explorada neste artigo propõe que a variável educacional é uma dimensão central para compreender essas manifestações culturais. É conhecido que, desde as famílias de elite e até mesmo nas classes populares, os investimentos em educação são estratégias para manutenção ou possíveis ascensões sociais. Estes investimentos são realizados, por vezes, financeiramente, como, por exemplo, com a destinação de recursos para $\mathrm{o}$ pagamento de mensalidades em instituições privadas (PEROSA; DANTAS, 2017), mas não apenas.

Diante da emergência dos saraus literários, apresenta-se aqui os resultados da pesquisa de campo, realizada entre 2014 e 2016, visitando saraus literários, entrevistando "líderes" desses empreendimentos e uma enquete por questionário sobre o público presente em alguns destes saraus nos quais pudemos realizar a pesquisa. A hipótese geral explorada neste artigo propõe que a variável educacional é uma dimensão central para compreender essas manifestações culturais.

\section{Uma literatura periférica}

A antropóloga Érica Peçanha analisou o surgimento da Literatura Periférica em São Paulo, considerando como marco do início do movimento a primeira edição de uma série especial da revista Caros Amigos, em 2001, que trouxe o título "Literatura Marginal", e foi organizada pelo escritor Ferréz, morador do Capão Redondo, bairro da periferia da zona sul de São Paulo.

No editorial do primeiro número da série, considerado o manifesto do movimento, Ferréz afirma que no Brasil a história dos pobres, negros, índios, sempre ficou em segundo plano, sendo suas vidas regidas pela absoluta necessidade de privilegiar 0 trabalho em detrimento do estudo para sobreviver.

No texto do manifesto, o escritor aposta que a publicação contribuiria para uma mudança dessa situação, incluindo novos sujeitos e seus discursos na cena literária: 
Jogando contra a massificação que domina e aliena cada vez mais os assim chamados por eles de 'excluídos sociais' e para nos certificar de que o povo da periferia/favela/gueto tenha sua colocação na história e não fique mais quinhentos anos jogado no limbo cultural de um país que tem nojo de sua própria cultura (FERRÉZ, 2001).

Ainda hoje, temos $40 \%$ dos jovens brasileiros que não concluem a escola secundária e estão inseridos no mercado de trabalho, sendo grande parte deste contingente formado por jovens negros. Com a difusão do ensino, essa literatura marginal dos escritores da periferia se torna virtualmente possível, e se auto afirma considerando como marginais aqueles que, historicamente, foram excluídos socioeconomicamente, que vivem às margens e que, por estigma e preconceito, são considerados marginais, perigosos para a sociedade, e também por estarem fora do circuito literário tradicional e pela temática de suas obras voltarem-se para relatar situações e condições dos moradores da periferia do Brasil, com sua linguagem característica e seu dialeto próprio.
Diante desse quadro, é possível considerar que, por mais que na história literária brasileira existissem autores advindos das camadas populares e mais pobres da sociedade, o movimento literário marginal/periférico se destacou por ser o primeiro a reivindicar esta origem como motivação para suas produções específicas e diferenciadas em um dado período histórico.

$$
\text { É importante considerar o }
$$
contexto sócio-histórico que permitiu aos moradores das regiões periféricas essa identificação com o espaço social em que viviam. Sobre este fenômeno, o sociólogo Tiaraju D'Andrea Pablo (2013) sustenta a hipótese de que a partir da década de 1990 havia condições para emergir uma geração que potencializou o termo, outrora negativo, para uma posição de luta e defesa do local em que vivem.

Pablo classifica esse grupo formado por 'sujeitos periféricos', pessoas que assumem as condições sociais específicas em que vivem, compreendem as origens e problemas que caracterizam este espaço, e passam a intervir assertivamente na tentativa de modificar tais condições, sobretudo por meio da arte. Pablo 
identifica esse movimento de tomada de posição a partir do contexto econômico mais favorável nos territórios periféricos entre os anos 1990 e 2000, quando o acesso a saneamento básico, moradia, entre outros, tornou-se um pouco mais consolidado, e o surgimento da cultura hip hop, e presença de organizações sociais também contribuíram para a ampliação do capital cultural desses sujeitos ${ }^{12}$.

Dentre esses coletivos culturais, destacam-se grupos que organizam os saraus, que passam a acontecer regularmente em bairros da periferia de São Paulo a partir dos anos 2000. Os saraus são encontros regulares realizados em espaços variados de convívio nos bairros periféricos, nos quais acontecem declamações de poesia, apresentações de músicas, dança, cenas teatrais, dentre outras atividades. A literatura é a manifestação artística privilegiada

\footnotetext{
${ }^{12}$ Contra a ideologia dos dons naturais e do mérito individual, Bourdieu desenvolve a noção de capital cultural, assim definindo-a: "Cada família transmite a seus filhos, através de canais indiretos e não diretos, um certo capital cultural e ethos, um sistema de valores implícitos e profundamente internalizados, que ajuda a definir, entre outras coisas, atitudes em relação ao capital cultural e à instituição escolar". A esse respeito, consultar "A escola conservadora” (BOURDIEU, 2003).
}

destes eventos e recebe um tratamento especial durante a realização dos saraus.

Trata-se de um momento de encontro entre escritores, lançamento e venda de livros e divulgação dos trabalhos pessoais dos membros desse campo literário específico. Em muitos deles, os saraus acontecem em bares, com serviços de comida e bebida, apresentações musicais e, sobretudo, espaço para leitura de textos poéticos.

Um dos primeiros saraus de maior relevância nesse cenário é o Sarau da Cooperifa (Cooperativa Cultural da Periferia), que, desde 2001, acontece semanalmente no Jardim Guarujá, em Taboão da Serra, divisa com o extremo sul da capital paulistana. Atualmente no Bar do Batidão, liderado pelo poeta Sérgio Vaz, um dos autores que participou das edições da publicação Literatura Marginal da revista Caros Amigos.

Nascimento (2011) considera que os saraus, sobretudo 0 da Cooperifa, instituíram um novo modelo de produção e divulgação cultural que se disseminou nos bairros de periferia e o termo periférico passou a ser 
utilizado para classificar e potencializar estas novas práticas:

a articulação em torno de elaborações sobre a periferia e sua cultura singular é capaz de revelar um processo específico de produção cultural. Isso porque não somente os produtos e circuitos de consumo periféricos apresentam-se como soluções criativas ao mercado cultural, mas também porque a associação do trabalho desenvolvido ao espaço social da periferia permitiu que fosse elaborada uma agenda comum a diferentes grupos, movimentos, coletivos, associações e artistas da periferia (NASCIMENTO, 2011, p. 15).

O Sarau da Cooperifa, dentre outros precursores, serviu de exemplo e inspiração para que muitos outros saraus passassem a acontecer nos bairros periféricos de São Paulo. Os moradores de outras regiões, que frequentavam os eventos que tiveram início na zona sul da cidade, passaram a organizar saraus em seus próprios bairros, disseminando 0 mesmo modelo.

Os eventos se tornaram, ainda, um meio pelo qual os escritores passam a se integrar e difundir a produção literária enquanto um movimento, e não apenas por iniciativas isoladas. Propiciando que os autores possam lançar seus livros, apresentar suas poesias, divulgar suas agendas de trabalho, nos saraus o que podemos classificar que se consolida o que podemos nomear como "campo literário periférico", na medida em que se mantém "relativamente autônomo", com ações e práticas voltadas a si mesmo.

Esta rede de edições "independentes" ou "alternativas" (às grandes editoras) seria impossível e incompreensível sem um circuito autônomo de distribuição e comercialização das obras. $E$ os encontros presenciais nos saraus poéticos das periferias parecem cobrir esta necessidade, chegando a constituir uma espécie de "sistema literário" (no sentido de Antonio Candido) paralelo, funcionando de forma independente nas periferias de São Paulo (SALOM, 2014, p. 82).

Para comprovar que os saraus compõem um fenômeno particular que acontece nos bairros periféricos de São Paulo, em um levantamento informal realizado durante a pesquisa em 2015, alcançou-se o número de 22 saraus regulares que servem como amostra desse movimento literário. 
SILVA, Lívia Lima da; PEROSA, Graziela Serroni. Trajetórias de escritores e os saraus literários nas periferias de São Paulo. PragMATIZES - Revisto Latino-Americana de Estudos em Cultura, Niterói/RJ, Ano 12, n. 22, p. 79-112, mar. 2022.

Quadro 2. Saraus regulares de São Paulo (2015)

\begin{tabular}{|c|c|c|}
\hline SARAUS & $\begin{array}{l}\text { Subprefeitur } \\
\text { a }\end{array}$ & $\begin{array}{l}\text { Espaço de } \\
\text { Realização }\end{array}$ \\
\hline 1.Praçarau & Campo Limpo & Praça pública \\
\hline $\begin{array}{ll}\text { Sarau } & \text { A } \\
\text { plenos } & \\
\text { pulmões } & \end{array}$ & Sé & $\begin{array}{l}\text { Centro } \\
\text { Cultural }\end{array}$ \\
\hline $\begin{array}{l}\text { Sarau Antene- } \\
\text { se }\end{array}$ & Campo Limpo & Bar \\
\hline $\begin{array}{l}\text { Sarau Bodega } \\
\text { do Brasil }\end{array}$ & Sé & Bar \\
\hline $\begin{array}{l}\text { Sarau da } \\
\text { Ademar }\end{array}$ & $\begin{array}{l}\text { Cidade } \\
\text { Ademar }\end{array}$ & Bar \\
\hline $\begin{array}{ll}\text { Sarau } & \text { da } \\
\text { Biblioteca } & \\
\text { Ejaac } & \end{array}$ & Campo Limpo & Biblioteca \\
\hline $\begin{array}{l}\text { Sarau da } \\
\text { Brasa }\end{array}$ & $\begin{array}{l}\text { Freguesia/ } \\
\text { Brasilândia }\end{array}$ & Bar \\
\hline $\begin{array}{ll}\text { Sarau } & \text { da } \\
\text { Cooperifa } & \end{array}$ & Campo Limpo & Bar \\
\hline $\begin{array}{l}\text { Sarau do } \\
\text { Beco }\end{array}$ & Jabaquara & $\begin{array}{l}\text { Espaço } \\
\text { cultural }\end{array}$ \\
\hline $\begin{array}{l}\text { Sarau do } \\
\text { Binho }\end{array}$ & Campo Limpo & Bar/teatro \\
\hline $\begin{array}{l}\text { Sarau do } \\
\text { Grajaú }\end{array}$ & $\begin{array}{l}\text { Capela do } \\
\text { Socorro }\end{array}$ & $\begin{array}{l}\text { Espaço } \\
\text { cultural }\end{array}$ \\
\hline $\begin{array}{l}\text { Sarau do } \\
\text { Kintal }\end{array}$ & $\begin{array}{l}\text { Freguesia/ } \\
\text { Brasilândia }\end{array}$ & Moradia \\
\hline $\begin{array}{l}\text { Sarau do } \\
\text { Peixe }\end{array}$ & Itaim Paulista & $\begin{array}{l}\text { Espaço } \\
\text { cultural }\end{array}$ \\
\hline Sarau do Vinil & $\begin{array}{l}\text { Cidade } \\
\text { Ademar }\end{array}$ & $\begin{array}{l}\text { Espaço } \\
\text { cultural }\end{array}$ \\
\hline $\begin{array}{l}\text { Sarau dos } \\
\text { Mesquiteiros }\end{array}$ & $\begin{array}{l}\text { Ermelino } \\
\text { Matarazzo }\end{array}$ & Escola \\
\hline Sarau d'Quilo & Perus & $\begin{array}{l}\text { Espaço } \\
\text { cultural }\end{array}$ \\
\hline $\begin{array}{l}\text { Sarau Elo da } \\
\text { Corrente }\end{array}$ & $\begin{array}{l}\text { Pirituba/ } \\
\text { Jaraguá }\end{array}$ & Bar \\
\hline
\end{tabular}

www.periodicos.uff.br/pragmatizes - ISSN 2237-1508 (Dossiê "Coletivos culturais - resistências, disputas e potências")

\begin{tabular}{|l|l|l|}
\hline SARAUS & $\begin{array}{l}\text { Subprefeitur } \\
\text { a }\end{array}$ & $\begin{array}{l}\text { Espaço de } \\
\text { Realização }\end{array}$ \\
\hline $\begin{array}{l}\text { Sarau Encontro de } \\
\text { utopias }\end{array}$ & Sé & Bar \\
\hline $\begin{array}{l}\text { Sarau } \\
\text { Movimento } \\
\text { Aliança da } \\
\text { Praça - MAP }\end{array}$ & $\begin{array}{l}\text { São Miguel } \\
\text { Paulista }\end{array}$ & Praça pública \\
\hline $\begin{array}{l}\text { Sarau O que } \\
\text { dizem os } \\
\text { umbigos Itaim Paulista }\end{array}$ & $\begin{array}{l}\text { Escola de } \\
\text { samba }\end{array}$ \\
\hline $\begin{array}{l}\text { Sarau } \\
\text { Perifatividade }\end{array}$ & Ipiranga & $\begin{array}{l}\text { Espaço } \\
\text { cultural }\end{array}$ \\
\hline $\begin{array}{l}\text { Sarau Preto } \\
\text { no Branco }\end{array}$ & M'Boi Mirim & $\begin{array}{l}\text { Espaço } \\
\text { cultural }\end{array}$ \\
\hline
\end{tabular}

Fonte: Páginas do facebook de saraus literários em São Paulo.

Apesar da heterogeneidade das informações disponíveis nas páginas dos saraus, retivemos aqui o nome do sarau, sua localização na cidade e o tipo de espaço em que ocorriam ${ }^{13}$. Observando os nomes dos saraus, sua capilaridade e heterogeneidade de locais e situações nas quais tiveram origem. Nota-se uma concentração dos saraus em subprefeituras de periferias mais precárias como M'Boi Mirim, Perus, São Miguel Paulista e em periferias mais intermediárias

\footnotetext{
${ }^{13}$ Outras informações pertinentes, como a data de fundação, não foram localizadas, de maneira uniforme e comparável, para todos os saraus.
} 
como Ermelino Matarazzo. Para além das periferias e considerando-se a heterogeneidade social que caracteriza boa parte da cidade (Marques, 2014), temos diversos saraus na região da Sé, que corresponde ao antigo centro da cidade e no Ipiranga. Os nomes trazem consigo informações sobre a história destes empreendimentos. Por meio deles, podemos ver que eles aconteceram em praças públicas, bibliotecas, igrejas, bares, escolas, centros culturais, em geral, localizados no bairro de residência dos seus fundadores. Alguns desses nomes trazem em si uma conotação mais política como "a plenos pulmões", "encontro de utopias" , "Periferatividade" ou "o que dizem os umbigos", "Sobrenome liberdade" que dão pistas sobre como eles funcionavam como uma espécie de refúgio, de encontro entre os pares, de retorno reflexivo sobre a condição de sujeitos periféricos (Pablo). Para este estudo, foram selecionados o Sarau do Binho, o Elo da Corrente, o Sarau do Map e o Sobrenome Liberdade, procurando considerar os eventos em diferentes regiões da cidade.
Quadro 3. Saraus da pesquisa de campo

\begin{tabular}{|c|c|}
\hline Sarau & Subprefeitura \\
\hline $\begin{array}{l}\text { 1. Sarau Elo da } \\
\text { Corrente }\end{array}$ & Pirituba \\
\hline $\begin{array}{l}\text { 2. Sarau do MAP - } \\
\text { Movimento } \\
\text { Aliança pela } \\
\text { Praça }\end{array}$ & São Miguel Paulista \\
\hline 3. Sarau do Binho & Campo Limpo \\
\hline $\begin{array}{l}\text { 4. Sarau } \\
\text { Sobrenome } \\
\text { Liberdade }\end{array}$ & Capela do Socorro \\
\hline
\end{tabular}

$$
\text { Situando-os no espaço }
$$

geográfico podemos observar melhor a distribuição no tecido social da cidade.

Figura 5 - Mapa da cidade de São Paulo por distritos

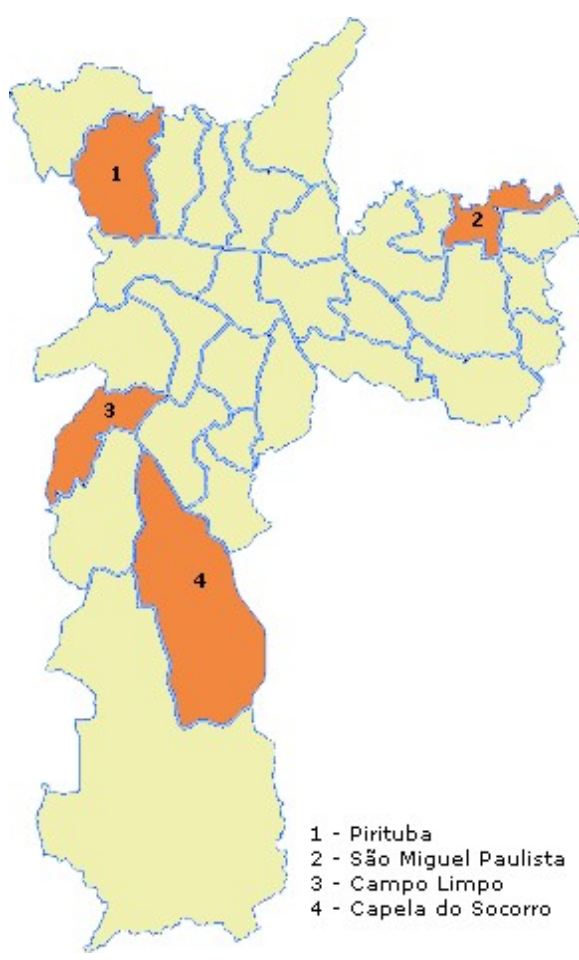

Fonte: Prefeitura de São Paulo, editado por Lívia Lima da Silva. 
SILVA, Lívia Lima da; PEROSA, Graziela Serroni. Trajetórias de escritores e os saraus literários nas periferias de São Paulo. PragMATIZES - Revista Latino-Americana de Estudos em Cultura, Niterói/RJ, Ano 12, n. 22, p. 79-112, mar. 2022.

As imagens realizadas durante a pesquisa ajudam a corroborar os demais indícios da atmosfera que caracteriza os saraus e essa prática cultural:

Figuras 1 e 2 - Fotos Sarau do Binho e Sarau do Movimento Aliança pela Praça

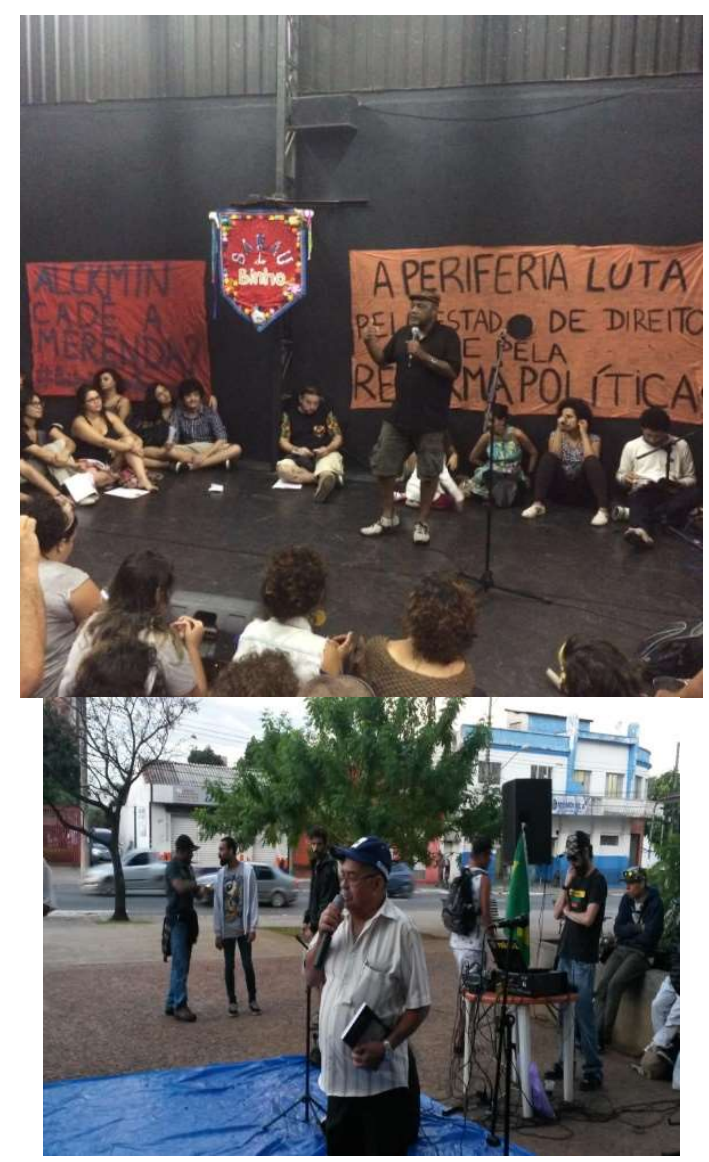

Fonte: Fotos por Lívia Lima da Silva.

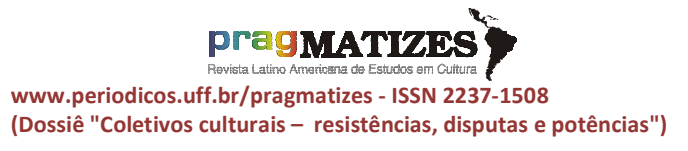

Figuras 3 e 4 - Fotos do Sarau Elo da Corrente e Sarau Sobrenome Liberdade

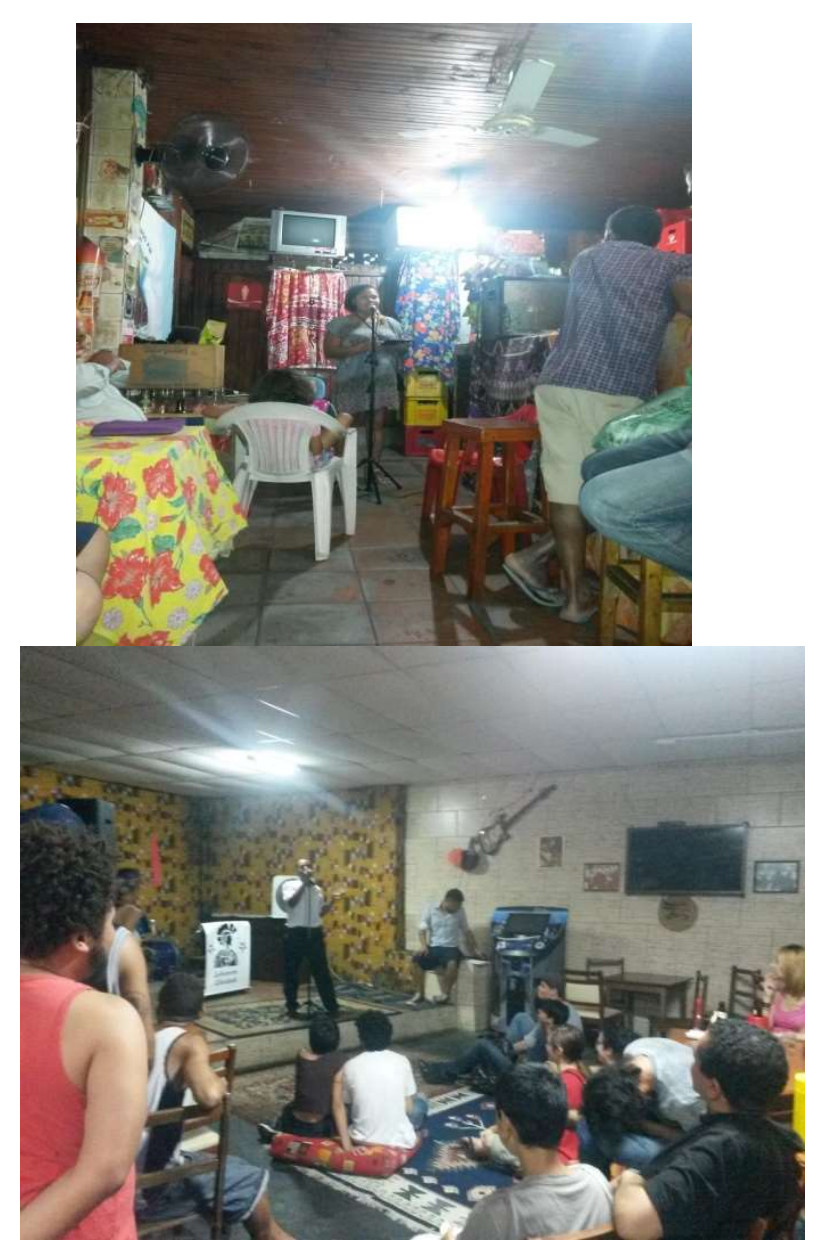

Fonte: Fotos por Lívia Lima da Silva.

\section{Os poetas e escritores nas periferias de São Paulo}

Por meio de questionários aplicados durante as realizações dos saraus, entre os meses de agosto e novembro de 2015, buscou-se extrair uma amostra que representasse entre 10 a $20 \%$ do público total estimado. 0 questionário solicitou informações sobre idade, raça, formação escolar, profissão, escolaridade e profissão dos 
pais, local de nascimento do participante e dos pais, bairro onde mora, além de frequência no sarau e outros hábitos culturais.

Com base nas respostas, algumas informações se mostraram mais relevantes para a tentativa de estabelecer as características que compõem os objetivos de análise da pesquisa:

- $66 \%$ têm entre 15 a 29 anos;

- $73 \%$ nasceram em São Paulo;

- $26 \%$ têm pai e mãe nordestinos;

- $33 \%$ se declaram negros, $58 \%$ negros ou pardos;

- $57 \%$ têm ensino superior completo ou incompleto;

- $77 \%$ possuem Ensino Médio completo, considerando os que chegaram no Ensino Superior.

Trata-se de um público em sua maioria jovem, que nasceu em São Paulo, mas descende das primeiras gerações que habitaram as regiões periféricas da cidade, sendo aproximadamente um entre quatro, composta por migrantes de estados do nordeste do país.

Os dados sobre cor e raça indicam que mais da metade da mostra se declara pardo ou negro, e que são esses que compõem a maioria dos moradores dos bairros periféricos, se relacionarmos com dados de renda do IBGE, por exemplo, que apontam que $76 \%$ da população mais pobre do Brasil se declara negra.

Esse aumento na escolaridade progressivo, que vem favorecendo as novas gerações, também se revela nos dados coletados ao comparar a escolaridade dos entrevistados com a escolaridade de seus pais. Enquanto o índice de nível superior dos frequentadores dos saraus é de $57 \%$, o de suas mães é de $24 \%$ e o de seus pais, $15 \%$.

Esta característica reforçou a hipótese de que a realização dos saraus, dentre tantos outros movimentos culturais que passam a emergir nos bairros periféricos a partir dos anos 2000, se relacionam com uma mudança de habitus das frações de classe que compõem a população destas regiões, influenciada por uma ampliação do capital cultural destes moradores que, dentre outros processos em suas trajetórias, passam a ter acesso à escola secundária completa e ingressam na universidade.

Os dados dos questionários apontam que $60 \%$ do público escreve poesia, e $43 \%$ se apresentam nos 
saraus, declamando textos, próprios ou não. Esse número nos leva a uma interpretação de que os saraus atraem um público específico formado por pessoas que se interessam por literatura, não apenas como consumo cultural, mas também como produtores.

No estudo de campo foram realizadas oito entrevistas com escritores/poetas atuantes nos saraus selecionados, e que se destacam dentro da realização destes, sendo que, em cada um dos quatro saraus, foram escolhidos um homem e uma mulher para representar o grupo que compõem.

A partir das entrevistas, foi possível mapear as origens de cada um dos escritores, considerando o local de nascimento deles e de seus pais, o que aponta em alguns casos para um relevante dado relacionado ao processo de migração de moradores da região Nordeste para São Paulo, além de dados sobre os tipos de profissão mais comuns dos moradores periféricos.

Quadro 4 - Origem Social dos poetas dos saraus

\begin{tabular}{|c|c|c|c|c|c|c|c|}
\hline Escritor & Sarau & Idade & $\begin{array}{l}\text { Local } \\
\text { de } \\
\text { Nasci } \\
\text { mento }\end{array}$ & $\begin{array}{l}\text { Nascimento } \\
\text { pai }\end{array}$ & $\begin{array}{l}\text { Nascimento } \\
\text { mãe }\end{array}$ & $\begin{array}{l}\text { Profissão } \\
\text { pai }\end{array}$ & $\begin{array}{l}\text { Profissão } \\
\text { mãe }\end{array}$ \\
\hline $\begin{array}{l}\text { Michel } \\
\text { Yakini }\end{array}$ & $\begin{array}{l}\text { Elo da } \\
\text { Corren } \\
\text { te }\end{array}$ & 35 & $\begin{array}{l}\text { São } \\
\text { Paulo }\end{array}$ & São Paulo & São Paulo & $\begin{array}{l}\text { Coletor de } \\
\text { material } \\
\text { reciclável }\end{array}$ & $\begin{array}{l}\text { aposentada } \\
\text { (cozinheira } \\
\text { de escola) }\end{array}$ \\
\hline $\begin{array}{l}\text { Raquel } \\
\text { Almeida }\end{array}$ & $\begin{array}{l}\text { Elo da } \\
\text { Corren } \\
\text { te }\end{array}$ & 28 & $\begin{array}{l}\text { São } \\
\text { Paulo }\end{array}$ & Bahia & Bahia & $\begin{array}{l}\text { caminhonei } \\
\text { ro }\end{array}$ & $\begin{array}{l}\text { cozinheira } \\
\text { em escola }\end{array}$ \\
\hline $\begin{array}{l}\text { Robson } \\
\text { de } \\
\text { Oliveira } \\
\text { Padial }\end{array}$ & $\begin{array}{l}\text { Sarau } \\
\text { do } \\
\text { Binho }\end{array}$ & 51 & $\begin{array}{l}\text { São } \\
\text { Paulo/ } \\
\text { Taboã } \\
\text { o da } \\
\text { Serra }\end{array}$ & $\begin{array}{lr}\text { São } & \text { Paulo } \\
\text { (São } & \text { José } \\
\text { do } & \text { Rio } \\
\text { Preto) } & \end{array}$ & $\begin{array}{l}\text { São Paulo } \\
\text { (Tambaú) }\end{array}$ & $\begin{array}{l}\text { comerciant } \\
\mathrm{e}\end{array}$ & $\begin{array}{l}\text { Auxiliar de } \\
\text { enfermagem }\end{array}$ \\
\hline
\end{tabular}




\begin{tabular}{|l|l|l|l|l|l|l|l|}
$\begin{array}{l}\text { Tula } \\
\text { Pilar } \\
\text { Ferreira }\end{array}$ & $\begin{array}{l}\text { Sarau } \\
\text { do } \\
\text { Binho }\end{array}$ & 45 & $\begin{array}{l}\text { Minas } \\
\text { Gerais }\end{array}$ & $\begin{array}{l}\text { desconhecid } \\
\text { (Minas } \\
\text { Gerais) }\end{array}$ & Minas gerais & $\begin{array}{l}\text { desconheci } \\
\text { do }\end{array}$ & doméstica \\
\hline $\begin{array}{l}\text { Mauricio } \\
\text { Francisc } \\
\text { o dos } \\
\text { Santos } \\
\text { (Mano } \\
\text { Ril) }\end{array}$ & $\begin{array}{l}\text { Sobre } \\
\text { nome } \\
\text { Liberd }\end{array}$ & 30 & $\begin{array}{l}\text { São } \\
\text { Paulo }\end{array}$ & Bahia & Bahia & pedreiro & doméstica \\
\hline $\begin{array}{l}\text { Michele } \\
\text { Santos }\end{array}$ & $\begin{array}{l}\text { Sobre } \\
\text { nome } \\
\text { Liberd } \\
\text { ade }\end{array}$ & 35 & $\begin{array}{l}\text { São } \\
\text { Paulo }\end{array}$ & São Paulo & Alagoas & $\begin{array}{l}\text { metalúrgico } \\
\text { pequeno }\end{array}$ & $\begin{array}{l}\text { doméstica, } \\
\text { dona } \\
\text { casa }\end{array}$ \\
\hline $\begin{array}{l}\text { Rafael } \\
\text { Carneva } \\
\text { lli }\end{array}$ & $\begin{array}{l}\text { Sarau } \\
\text { do } \\
\text { MAP }\end{array}$ & 26 & $\begin{array}{l}\text { São } \\
\text { Paulo }\end{array}$ & Itália & Bahia & $\begin{array}{l}\text { pequeno } \\
\text { comerciant } \\
\text { e }\end{array}$ & $\begin{array}{l}\text { pequeno } \\
\text { comerciante }\end{array}$ \\
\hline $\begin{array}{l}\text { Mariana } \\
\text { Felix }\end{array}$ & $\begin{array}{l}\text { Sarau } \\
\text { do } \\
\text { MAP }\end{array}$ & 30 & $\begin{array}{l}\text { São } \\
\text { Paulo }\end{array}$ & $\begin{array}{l}\text { São Paulo } \\
\text { (Campinas) }\end{array}$ & Paraíba & $\begin{array}{l}\text { eletricista } \\
\text { (padrasto) }\end{array}$ & $\begin{array}{l}\text { pedagoga } \\
\end{array}$ \\
\hline
\end{tabular}

Fonte: elaborado pelas autoras

Quadro 5 - Escolaridade dos poetas dos saraus

\begin{tabular}{|l|l|l|l|l|l|l|}
\hline $\begin{array}{c}\text { Escrito } \\
\mathbf{r}\end{array}$ & $\begin{array}{c}\text { Escolarida } \\
\text { de }\end{array}$ & $\begin{array}{l}\text { Formaçã } \\
\text { o } \\
\text { superior }\end{array}$ & $\begin{array}{c}\text { Universida } \\
\text { de }\end{array}$ & $\begin{array}{c}\text { Escolaridad } \\
\text { e pai }\end{array}$ & $\begin{array}{l}\text { Escolaridad } \\
\text { e mãe }\end{array}$ & $\begin{array}{c}\text { Espaços de } \\
\text { "educação } \\
\text { não formal" }\end{array}$ \\
\hline $\begin{array}{l}\text { Michel } \\
\text { Yakini }\end{array}$ & $\begin{array}{l}\text { superior } \\
\text { incompleto } \\
\text { (interrompe } \\
\text { u) }\end{array}$ & $\begin{array}{l}\text { Ciências } \\
\text { Sociais, } \\
\text { Letras }\end{array}$ & UFPR, USP & $\begin{array}{l}\text { fundamental } \\
\text { incompleto }\end{array}$ & $\begin{array}{l}\text { ensino } \\
\text { médio } \\
\text { completo } \\
\text { (supletivo) }\end{array}$ & $\begin{array}{l}\text { futebol em } \\
\text { centro } \\
\text { esportivo húblico, hip } \\
\text { hop, rádio } \\
\text { comunitária }\end{array}$ \\
\hline
\end{tabular}


SILVA, Lívia Lima da; PEROSA, Graziela Serroni. Trajetórias de escritores e os saraus literários nas periferias de São Paulo. PragMATIZES - Revisto Latino-Americana de Estudos em Cultura, Niterói/RJ, Ano 12, n. 22, p. 79-112, mar. 2022.

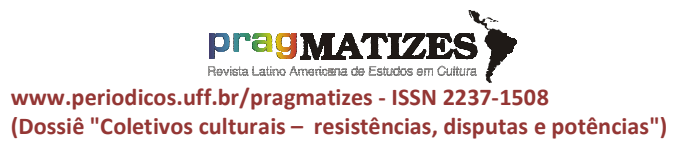

\begin{tabular}{|c|c|c|c|c|c|c|}
\hline $\begin{array}{l}\text { Raquel } \\
\text { Almeid } \\
\text { a }\end{array}$ & $\begin{array}{l}\text { superior } \\
\text { incompleto } \\
\text { (interrompe } \\
\text { u) }\end{array}$ & Música & Uniesp & $\begin{array}{l}\text { fundamental } \\
\text { incompleto }\end{array}$ & $\begin{array}{l}\text { fundamental } \\
\text { incompleto }\end{array}$ & $\begin{array}{l}\text { igreja } \\
\text { evangélica, hip } \\
\text { hop, rádio } \\
\text { comunitária }\end{array}$ \\
\hline $\begin{array}{l}\text { Robson } \\
\text { de } \\
\text { Oliveira } \\
\text { Padial }\end{array}$ & $\begin{array}{l}\text { ensino } \\
\text { médio } \\
\text { completo }\end{array}$ & - & - & $\begin{array}{l}\text { ensino } \\
\text { médio } \\
\text { completo }\end{array}$ & $\begin{array}{l}\text { ensino } \\
\text { superior } \\
\text { completo }\end{array}$ & $\begin{array}{l}\text { biodança, } \\
\text { viagem para o } \\
\text { exterior, } \\
\text { homeopatia }\end{array}$ \\
\hline $\begin{array}{l}\text { Tula } \\
\text { Pilar } \\
\text { Ferreira }\end{array}$ & $\begin{array}{l}\text { ensino } \\
\text { médio } \\
\text { completo } \\
\text { (supletivo) }\end{array}$ & - & - & $\begin{array}{l}\text { desconhecid } \\
\text { o }\end{array}$ & $\begin{array}{l}\text { não } \\
\text { escolarizada }\end{array}$ & $\begin{array}{l}\text { sarau, cultura } \\
\text { africana }\end{array}$ \\
\hline $\begin{array}{l}\text { Mauríci } \\
\text { o } \\
\text { Francis } \\
\text { co dos } \\
\text { Santos } \\
\text { (Mano } \\
\text { Ril) }\end{array}$ & $\begin{array}{l}\text { superior } \\
\text { incompleto } \\
\text { (interrompe } \\
\text { u) }\end{array}$ & $\begin{array}{l}\text { Engenhar } \\
\text { ia }\end{array}$ & Uninove & $\begin{array}{l}\text { não } \\
\text { escolarizado }\end{array}$ & $\begin{array}{l}\text { fundamental } \\
\text { incompleto }\end{array}$ & hip hop \\
\hline $\begin{array}{l}\text { Michele } \\
\text { Santos }\end{array}$ & $\begin{array}{l}\text { superior } \\
\text { completo }\end{array}$ & Letras & Uniban & $\begin{array}{l}\text { ensino } \\
\text { médio } \\
\text { completo }\end{array}$ & $\begin{array}{l}\text { fundamental } \\
\text { incompleto }\end{array}$ & $\begin{array}{l}\text { igreja } \\
\text { evangélica, } \\
\text { cultura rock }\end{array}$ \\
\hline $\begin{array}{l}\text { Rafael } \\
\text { Carnev } \\
\text { alli }\end{array}$ & $\begin{array}{l}\text { superior } \\
\text { incompleto } \\
\text { (cursando) }\end{array}$ & Letras & Unicsul & $\begin{array}{l}\text { fundamental } \\
\text { completo }\end{array}$ & $\begin{array}{l}\text { fundamental } \\
\text { completo }\end{array}$ & amigos artistas \\
\hline $\begin{array}{l}\text { Marian } \\
\text { a Felix }\end{array}$ & $\begin{array}{l}\text { superior } \\
\text { incompleto } \\
\text { (interrompe } \\
\text { u) }\end{array}$ & Letras & Unicsul & $\begin{array}{l}\text { ensino } \\
\text { médio } \\
\text { completo }\end{array}$ & $\begin{array}{l}\text { superior } \\
\text { completo } \\
\text { (pós- } \\
\text { graduação) }\end{array}$ & teatro, futebol \\
\hline
\end{tabular}

Fonte: elaborado pelas autoras

É interessante notar ao comparar a escolaridade dos poetas com a de seus pais, como ela indica

\begin{abstract}
uma possível ampliação de oportunidades propiciadas para os mais jovens. Todos conseguiram
\end{abstract}


completar a educação básica, o que não era tão natural em décadas anteriores.

Conforme Bourdieu considera, o espaço escolar, e o tempo despendido nele, são fundamentais para, além de adquirir aprendizado, estabelecer perspectivas em relação ao futuro e imaginar possibilidades.

A escola, facto que se esquece sempre, não é simplesmente um lugar onde se aprendem coisas, saberes, técnicas, etc., é também uma instituição que atribui títulos, quer dizer direitos, e confere no mesmo modo aspirações (BOURDIEU, 1984, p. 155).

Alguns dos escritores entrevistados também revelaram em entrevista que conseguiram bolsas e outras formas de contribuição para a permanência estudantil, como Raquel Almeida e Rafael Carnevalli, mas a maioria ingressou por meio de pagamentos de mensalidade em faculdades privadas, próximas às suas residências.

O índice de abandono do ensino superior se mostra um indicativo relevante, na medida em que pode sugerir alguns aspectos recorrentes nas trajetórias dos escritores, desde a inadaptação ao modelo e estrutura universitários, as dificuldades para se manter nos estudos, até dúvidas sobre a importância do diploma para a prática profissional e literária atual.

Vale notar o fato de quatro poetas dentre oito buscarem uma formação superior em Letras, o que denota que se trata de um grupo profissionalizado e com repertório para atuação na área literária. Neste sentido, a emergência dos saraus literários pode ser pensada como expressão do desejo e uma estratégia de profissionalização.

A maior parte deles ingressa no ensino superior pelas portas pelas quais, geralmente, entram os jovens das camadas populares: pelas licenciaturas. Cursam letras e com isso a aspiração a ser escritor, a investir seriamente nessa carreira. Ao contar com um público relativamente expressivo, os saraus literários unem a arte e o comércio, uma estratégia que favorece esses jovens intelectuais a se reinventarem, ainda que sem escapar ao trabalho instável e precário que eles compartilham com os

A "profissão" de escritor ou de artista é, com efeito, uma das menos codificadas que existem; uma das menos capazes também de definir (e de alimentar) completamentre aqueles que dela se valem e que, com muita 
frequência, só podem assumir a função que consideram como principal com a condição de ter uma profissão secundária da qual tiram seu rendimento principal (BOURDIEU, 2002, p. 257).

Também é importante destacar que, para além do acesso ao ensino superior, não concluído pela maioria dos entrevistados, outros processos e contatos, que definimos como "educação não formal", são fundamentais para compreender as práticas e a atuação deles no movimento cultural periférico, dentre eles, por exemplo, a cultura hip hop, que se revelou presente na juventude de muitos dos escritores.

Eu sempre escrevi música de Rap (...) Eu tenho três fases da minha vida, uma que eu só escrevia textos, a segunda que eu pegava esses textos e transforma em Rap, que eu tinha que coloca rima e poesia, e depois que eu conheci a Literatura eu desconstrui tudo isso aí... (Mano Ril, em entrevista em 2015 à pesquisadora).
Considerando que uma das hipóteses dessa pesquisa era verificar a relação entre o acesso ao ensino superior e a atuação dos sujeitos que se apresentam como poetas e escritores nos saraus, e que são reconhecidos como tal no grupo, podemos concluir que, de modo geral, os escritores mesmo não tendo efetivamente conseguido cursar, concluir ou dar prioridade à formação universitária, atribuem um valor significativo para sua realização, fortemente relacionado à formação intelectual e que também influencia na prática artística. 
Quadro 6 - Trajetória profissional dos poetas dos saraus

\begin{tabular}{|c|c|c|c|c|c|}
\hline Escritor & $\begin{array}{l}\text { Profissões } \\
\text { que já exerceu }\end{array}$ & $\begin{array}{c}\text { Atual } \\
\text { ocupação }\end{array}$ & $\begin{array}{l}\text { Livros } \\
\text { publicados }\end{array}$ & $\begin{array}{l}\text { Forma de } \\
\text { publicação }\end{array}$ & $\begin{array}{l}\text { Fonte de } \\
\text { renda }\end{array}$ \\
\hline $\begin{array}{l}\text { Michel } \\
\text { Yakini }\end{array}$ & $\begin{array}{l}\text { vendedor, } \\
\text { técnico de } \\
\text { telefonia, de } \\
\text { operador de } \\
\text { telemarketing }\end{array}$ & $\begin{array}{l}\text { produtor } \\
\text { cultural, } \\
\text { escritor, } \\
\text { editor }\end{array}$ & 2 & $\begin{array}{l}\text { independente } \\
\text { (selo editorial } \\
\text { Elo da } \\
\text { Corrente) }\end{array}$ & $\begin{array}{l}\text { editais, } \\
\text { oficinas, } \\
\text { palestras, } \\
\text { livros }\end{array}$ \\
\hline $\begin{array}{l}\text { Raquel } \\
\text { Almeida }\end{array}$ & $\begin{array}{l}\text { doméstica } \\
\text { (ajudava } \\
\text { mãe), } \\
\text { garçonete, }\end{array}$ & $\begin{array}{l}\text { produtora } \\
\text { cultural, } \\
\text { escritora }\end{array}$ & $\begin{array}{l}2 \text { (1 em co- } \\
\text { autoria) }\end{array}$ & $\begin{array}{l}\text { editais; } \\
\text { independente } \\
\text { (selo editorial } \\
\text { Elo da } \\
\text { Corrente) }\end{array}$ & $\begin{array}{l}\text { editais, } \\
\text { oficinas, } \\
\text { palestras, } \\
\text { livros }\end{array}$ \\
\hline $\begin{array}{l}\text { Robson } \\
\text { de Oliveira } \\
\text { Padial }\end{array}$ & $\begin{array}{l}\text { marceneiro, } \\
\text { vendedor, dono } \\
\text { de bar }\end{array}$ & $\begin{array}{l}\text { produtor } \\
\text { cultural, } \\
\text { homeopata }\end{array}$ & $\begin{array}{l}3 \text { (1 em co- } \\
\text { autoria e } 1 \\
\text { da } \\
\text { coletânea } \\
\text { do sarau) }\end{array}$ & $\begin{array}{l}\text { independente } \\
\text { e por editais }\end{array}$ & $\begin{array}{l}\text { sarau, } \\
\text { homeopatia }\end{array}$ \\
\hline $\begin{array}{l}\text { Tula Pilar } \\
\text { Ferreira }\end{array}$ & $\begin{array}{l}\text { doméstica, } \\
\text { babá, catadora } \\
\text { de recicláveis, } \\
\text { vendedora }\end{array}$ & $\begin{array}{l}\text { vendedora } \\
\text { de Revista } \\
\text { Ocas, atriz, } \\
\text { música }\end{array}$ & $\begin{array}{l}1 \quad \text { mais } \\
\text { participação } \\
\text { em } 2 \\
\text { coletâneas }\end{array}$ & $\begin{array}{l}\text { independente } \\
\text { e por editais }\end{array}$ & $\begin{array}{l}\text { venda de } \\
\text { revistas e } \\
\text { participação } \\
\text { em eventos }\end{array}$ \\
\hline $\begin{array}{l}\text { Mauricio } \\
\text { Francisco } \\
\text { dos } \\
\text { Santos } \\
\text { (Mano Ril) }\end{array}$ & $\begin{array}{l}\text { auxiliar } \\
\text { administrativo, } \\
\text { inspetor de } \\
\text { saneamento, } \\
\text { encarregado de } \\
\text { obra }\end{array}$ & $\begin{array}{l}\text { comerciante, } \\
\text { escritor }\end{array}$ & 1 & independente & $\begin{array}{l}\text { comércio no } \\
\text { bairro, } \\
\text { sarau, } \\
\text { oficinas, } \\
\text { participação } \\
\text { em eventos }\end{array}$ \\
\hline $\begin{array}{l}\text { Michele } \\
\text { Santos }\end{array}$ & $\begin{array}{l}\text { auxiliar } \\
\text { administrativo, } \\
\text { comércio } \\
\text { (ajudava a } \\
\text { família) }\end{array}$ & $\begin{array}{l}\text { professora } \\
\text { da rede } \\
\text { pública }\end{array}$ & 1 & independente & $\begin{array}{l}\text { salário, } \\
\text { livros, } \\
\text { participação } \\
\text { em eventos }\end{array}$ \\
\hline $\begin{array}{l}\text { Rafael } \\
\text { Carnevalli }\end{array}$ & $\begin{array}{l}\text { consultor } \\
\text { técnico de } \\
\text { veículos }\end{array}$ & educador & 1 & independente & $\begin{array}{l}\text { salário, } \\
\text { livros, } \\
\text { participação } \\
\text { em eventos }\end{array}$ \\
\hline $\begin{array}{l}\text { Mariana } \\
\text { Felix }\end{array}$ & $\begin{array}{l}\text { operadora de } \\
\text { telemarketing }\end{array}$ & $\begin{array}{l}\text { auxiliar } \\
\text { escolar da } \\
\text { rede pública }\end{array}$ & $\begin{array}{l}1 \text { livro e } 1 \\
\text { fanzine }\end{array}$ & independente & $\begin{array}{l}\text { salário, } \\
\text { livros, } \\
\text { participação } \\
\text { em eventos }\end{array}$ \\
\hline
\end{tabular}

Fonte: elaborado pelas autoras 


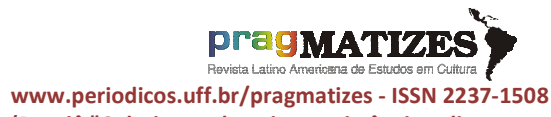

(Dossiê "Coletivos culturais - resistências, disputas e potências")
De modo geral, é possível afirmar que se trata de um grupo adulto, vindos das áreas de educação e cultura, principalmente, que empreende a atividade literária como uma prática profissional, e não consideram a si mesmos como autores amadores, ou exercitam apenas por lazer e distração, mais do que isso, sua fonte de renda deriva de atividades relacionadas ao sarau e à escrita.

Em relação aos livros, o quadro expõe que todos os escritores têm ao menos um livro publicado. Todos já possuem publicações autorais, além de participação em coletâneas e antologias como co-autores, nenhum deles, entretanto, por meio de uma grande editora, o que já nos mostra como eles ainda não fazem parte do campo literário legitimado pelo mercado.

Portanto, como eles ocupam uma posição marginal no campo literário considerado legítimo das grandes editoras. Mais uma vez verificamos que as editoras maiores e mais reconhecidas não fazem parte do universo do campo literário das periferias, que se desenvolve de forma particular e autônoma.

\section{Conclusões}

A intenção da pesquisa não foi rebaixar a literatura periférica ao nível apenas de fenômeno a ser analisado socialmente, sem descaracterizar sua relevância estética e política, mas procurou-se compreender quais são os fatores que reunidos contribuem para que ela se torne possível. Tal como Antonio Candido (2011) e tantos outros críticos literários consideram, as relações entre literatura e sociedade são processos contínuos de trocas de influências.

A literatura no Brasil, historicamente, sempre foi uma manifestação cultural das elites. Desde a história de formação do país, o modelo literário reconhecido e realizado foi baseado no modo de vida europeu, trazido no processo de colonização do território e desenvolvido entre algumas frações das chamadas classes superiores.

Considerando este contexto, a literatura brasileira nunca foi uma tradição cultural de grande abrangência e disseminação e, ainda hoje, a leitura não figura entre os principais hábitos culturais. Como consequência, o campo de produtores, considerando escritores, editores e 
empresários do segmento, também compõem um número de membros reduzido.

Ao longo do processo histórico, diversas manifestações culturais não foram consideradas, e, o que predomina no registro, são as manifestações culturais dos integrantes de grupos de elites econômicas e culturais - que consumiam, produziam e tinham suas obras reconhecidas e valorizadas no campo literário em formação, de modo que, em toda essa fase de constituição da produção literária brasileira, muitos grupos sociais não foram incluídos.

$\mathrm{Na}$ constituição do campo literário no Brasil, ainda que possamos identificar honrosas exceções, a produção literária tornou invisível os moradores das periferias das grandes cidades do Brasil, associados, objetiva e subjetivamente à condição de trabalhadores manuais, vivendo em situação de pobreza e marginalidade, com baixa escolaridade e de pouca familiaridade com a língua culta portuguesa, condição sinequa non para aspirar à literatura.No Brasil, casos como a da escritora Carolina Maria de Jesus, que se destacou devido a ainda ser novidade, na década de 50 do século $X X$, uma mulher negra moradora da favela se apresentar como escritora, mas cujos textos foram recebidos com desconfiança pela crítica à época, revelam esse preconceito velado que ainda persiste no campo cultural brasileiro, ainda que hoje ela venha sendo revisitada (MIRANDA, 2011). Foi preciso esperar até 2021 para que sua obra fosse objeto de uma exposição no circuito cultural reunido nos entornos da Avenida Paulista nos dias atuais.

Em pesquisa organizada por Regina Dalcastagnè na Universidade de Brasília, revelou-se que, dentre os autores brasileiros que tiveram livros publicados entre 1990 e 2004, cerca de $73 \%$ eram homens, $94 \%$ eram brancos, e a maioria viviam em São Paulo e no Rio de Janeiro, pólos do mercado editorial do país e eixo privilegiado do circuito cultural.

Os negros, historicamente negados de sua própria condição humana, enquanto escravos, e depois da abolição, marginalizados e excluídos das posições e campos de poder, incluindo o cultural, foram poucos os que ao longo do tempo 
fizeram parte do que se convencionou classificar como literatura brasileira.

Por mais que na história literária brasileira existissem autores advindos das camadas populares e mais pobres da sociedade, como Lima Barreto e Machado de Assis, o movimento literário marginal e periférico dos anos 2000 se destacou por ser o primeiro a reivindicar esta origem como motivação para suas produções específicas e diferenciadas em um dado período histórico.

O processo multideterminado de ampliação progressiva da conclusão da escola primária e o acesso à escola secundária trouxeram para os bancos escolares parte da população até então afastada do universo letrado. Com a difusão do ensino, essa literatura marginal dos escritores da periferia se torna virtualmente possível, se autoafirma considerando como marginais aqueles que, historicamente, foram excluídos socioeconomicamente, que vivem às margens e que, por estigma e preconceito, são considerados marginais, perigosos para a sociedade, e também por estarem fora do circuito literário tradicional e pela temática de suas obras voltarem-se para relatar situações e condições dos moradores da periferia do Brasil, com sua linguagem característica e seu dialeto próprio, são socialmente desvalorizados.

No início dessa pesquisa, partimos de uma suposição de que os escritores e poetas dos saraus das periferias se relacionavam de forma amadora com a prática literária, realizada em momentos de lazer. Ao longo do estudo de campo, no entanto, o que se verificou é que, de alguma forma, a literatura e as manifestações artísticas são vistas profissionalmente pelos sujeitos que compõem esse grupo. Graças à aquisição de capital cultural, à democratização do acesso, com todos os problemas do sistema de ensino brasileiro, irá contribuir para uma forma de subversão da posição social pela força do habitus.

As entrevistas também revelam que, mesmo aqueles que possuem outras fontes de renda, gostariam de se dedicar apenas à produção literária, o que demonstra que os escritores dos saraus compõem um grupo que busca cada vez mais a profissionalização e autonomia do campo. Os depoimentos indicam que os escritores conseguem manter uma estabilidade financeira 
razoável a partir de suas iniciativas culturais. Considerando que apenas o aumento da renda populacional não garantiria a produção literária em si mesma, a ampliação da escolaridade, com destaque para o acesso ao Ensino Superior, sobretudo, favoreceria em certa medida o contato das pessoas com novas formas de conhecimento, leituras, fundamentações teóricas, ou seja, a um acúmulo de capital cultural, que estimularia nesses novos atores sociais disposições e competências específicas para a criação artística. É a partir do capital cultural que os indivíduos estabelecem relações entre si e se colocam diante dos demais nos diferentes campos sociais. As condições que viabilizam a constituição do capital cultural são, dessa forma, estruturantes e influenciam as relações de dominação entre as classes, que se dá por meio de condições objetivas e subjetivas.

Os moradores de periferia, antes marginalizados dos campos dos saberes, se apropriam de conhecimentos variados - ao aceder o ensino superior, as licenciaturas e os cursos de letras e adquiridos em diferentes processos não estritamente educacionais - para reconstruírem narrativas acerca de si mesmos e de suas ideias, estas, sobretudo, partindo de uma valorização da "cultura comum" (WILLIAMS, 1958), não apenas da cultura legítima. Dessa forma, a cultura periférica, e dentro dela a literatura, é essencialmente uma prática de oposição aos sistemas vigentes, que institucionalizam determinadas manifestações artísticas, em detrimento de outras. Isso justifica, em certa medida, a forma como os escritores entrevistados se relacionam com o mercado editorial, rejeitando-o a princípio, reconhecendo nele estruturas que inviabilizam suas criações.

Entretanto, o estudo de campo e as entrevistas também demonstraram que 0 modelo tradicional de produção e divulgação da literatura, sobretudo a partir da publicação de livros, ainda é muito valorizado. Porém, as formas de publicação e distribuição se diferem do modo das grandes editoras, sendo a maioria dos livros publicados de forma independente e distribuídos para venda pelo próprio escritor durante a realização dos saraus. 
A produção literária dos moradores de periferia, ainda que associadas às manifestações dos saraus, encontros onde a oralidade, a música, a poesia, se tornam centrais, se encontra em um nível de desenvolvimento cada vez mais associado à profissionalização e institucionalização. As entrevistas apresentam o quanto as trajetórias dos escritores e o desejo pessoal deles estão ligados a uma autonomização em relação ao mundo do trabalho tradicional, e também uma convicção, uma aposta na prática literária que estão realizando.

Ao contrário da hipótese inicial desse projeto, os escritores de periferia não tratam a produção literária como uma atividade recreativa, como uma espécie de hobby e lazer que tenha que ser realizado no tempo livre em que não estão trabalhando, dentro das categorias de postos profissionais destinadas às classes populares. Ainda que esse fenômeno possa também ser possível e recorrente dentro da diversidade de pessoas e trajetórias que se encontram durante os saraus, as entrevistas apontam para um processo de busca de profissionalização e formação de uma carreira literária dos sujeitos, por vezes na contramão da carreira literária das grandes editoras

Entretanto, ainda que os poetas, em especial os selecionados no trabalho de campo, atualmente consigam se manter financeiramente das atividades literárias que promovem e participam, percebe-se que nem sempre a forma de aquisição de um bem ou retorno financeiro é, necessariamente, consequência do reconhecimento de seus produtos literários específicos, sendo necessárias também ações de atuação enquanto mobilizadores culturais, apresentadores, músicos, na relação que os saraus mantém enquanto práticas de lazer e entretenimento.

Não se pode dizer que os saraus pertencem apenas a uma categoria de arte naif porque seus organizadores se profissionalizam e conhecem os códigos de linguagem tanto quanto os escritores de classes altas. A principal diferença é que eles não são reconhecidos pelas instâncias de consagração do campo literário convencional. O que se conclui da análise das trajetórias dos poetas e escritores que participam dos saraus 
SILVA, Lívia Lima da; PEROSA, Graziela Serroni. Trajetórias de escritores e os saraus literários nas periferias de São Paulo. PragMATIZES - Revista Latino-Americana de Estudos em Cultura, Niterói/RJ, Ano 12, n. 22, p. 79-112, mar. 2022.

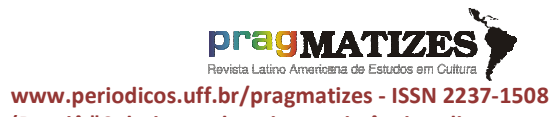

(Dossiê "Coletivos culturais - resistências, disputas e potências") selecionados no estudo de campo, é que todos desenvolvem suas práticas literárias com seriedade e de forma profissional e muitos deles dependem dessas ações como uma de suas fontes de renda.

Ainda que os escritores, principalmente os que valorizam mais a publicação de livros autorais, se apresentem enquanto artistas singulares no campo, a valorização da produção artística coletiva, e o sentimento de pertencimento e de identidade revelam características norteadoras das práticas dos saraus das periferias de São Paulo, que também se fazem presentes nas linguagens e estéticas produzidas por seus participantes. A inclusão desses sujeitos periféricos aumenta o repertório e a diversidade da produção literária, e contribui para maior representatividade da literatura brasileira, espelhando de fato a diversidade e pluralidade do país.

\section{Referências bibliográficas}

BONDUKI, Nabil; ROLNIK, Raquel. Periferias: ocupação do espaço e reprodução da força de trabalho. São Paulo: Prodeur/FAU-USP, 1979.
BOURDIEU, Pierre. A distinção: Crítica Social do julgamento. São Paulo: Edusp, Porto Alegre: Zouk, 2008.

BOURDIEU, Pierre. A economia das trocas simbólicas. São Paulo: Perspectiva, 2011.

BOURDIEU, Pierre. A escola conservadora: as desigualdades frente à escola e à cultura. In: NOGUEIRA, Maria Alice; CATANI, Afrânio (orgs.). Escritos de Educação. Petrópolis: Vozes, 2003. P. 41-64.

BOURDIEU, Pierre. As regras da arte. São Paulo: Companhia das Letras, 2002.

BOURDIEU, Pierre. O poder simbólico. Rio de Janeiro: Bertrand Brasil, 1989.

BOURDIEU, Pierre. Questões de sociologia. Lisboa: Fim de século, 1984.

BOURDIEU, Pierre. Razões práticas: sobre a teoria da ação. Campinas: Papirus, 1996.

CABANES, R.; GEORGES, I.; RIZEK, C.; TELLES, V. Saídas de emergência: ganhar/perder a vida na periferia de São Paulo. São Paulo: Boitempo, 2011.

CALDEIRA, Teresa. A política dos outros. O cotidiano dos moradores de periferia e o que pensam do poder e dos poderosos. São Paulo: Brasiliense, 1984

CANDIDO, Antonio. Literatura e Sociedade - Estudos de Teoria e História Literária. Rio de Janeiro: Ouro sobre Azul, 2011.

CASTEL, Robert. A discriminação negativa - Cidadãos ou Autóctones? Petrópolis: Vozes, 2008.

DALCASTAGNÈ, Regina. Literatura brasileira contemporânea: um território 
contestado. Rio de Janeiro: Editora da UERJ; Vinhedo: Horizonte, 2012.

FERRÉZ. Manifesto de abertura. In: Literatura Marginal (org.). Caros Amigos Especial. Literatura Marginal: a cultura da periferia. Ato I. São Paulo, agosto de 2001.

KOWARICK, Lucio. A espoliação urbana. Rio de Janeiro: Paz e Terra, 1979.

MIRANDA, Fernanda Rodrigues de. O campo literário afro-brasileiro e a recepção de Carolina Maria de Jesus. Revista Estação Literária, UEL, Londrina, Vagão-volume 8 parte $A, p$. 15-24, dez. 2011.

NASCIMENTO, Érica Peçanha. É tudo nosso! Produção cultural na periferia paulistana. (Doutorado em Antropologia). Universidade de São Paulo, 2011.

NASCIMENTO, Érica Peçanha. Literatura Marginal: os escritores da periferia entram em cena. (Mestrado em Antropologia). Universidade de São Paulo, 2006.

PABLO, Tiaraju d'Andrea. A formação dos sujeitos periféricos: Cultura e Política na periferia de São Paulo. (Doutorado em Sociologia). Universidade de São Paulo, 2013.

PEROSA, Graziela Serroni et alli. O espaço das desigualdades educativas no município de São Paulo. ProPosições, São Paulo, vol. 26, n. 2, p.99-118, 2015.

PEROSA, Graziela Serroni; DANTAS, Adriana Santiago Rosa. A escolha da escola privada em famílias dos grupos populares. Educ. Pesqui., São Paulo, v. 43 , n. 4 , p. 987-1004, out./dez., 2017.
SALOM, Julio Souto. Combater a subcidadania disputando o jogo literário: uma contribuição ao estudo da Literatura Marginal Periférica. (Mestrado em Literatura). Universidade Federal do Rio Grande do Sul, Porto Alegre, 2014.

VAZ, Sérgio. Cooperifa: Antropofagia periférica. Rio de Janeiro: Aeroplano, 2008.

WACQUANT, Loïc. Punir os pobres: a nova gestão da miséria nos Estados Unidos. Rio de Janeiro: Revan, 2003.

WILLIAMS, Raymond. A cultura é de todos. [Culture is Ordinary; traduação de Maria Elisa Cevasco] São Paulo: Departamento de Letras, USP, 1958. 